\title{
ARTYKUtY
}

\section{PRZEMIANY NARODOWOŚCIOWE W ŁATGALII}

\author{
WPROWADZENIE
}

$\mathrm{H}$

istoryczne Polskie Inflanty, zwane obecnie Łatgalią (łot. Latgale, niem. Lettgallen), położone są we wschodniej Łotwie i graniczą z Litwą, Białorusią i Federacją Rosyjską. Usytuowane są po północnej stronie Dźwiny (łot. Dangava), nad którą leży jej stolica Dyneburg (łot. Dangavpils, ros. Dzwińsk, niem. Dünaburg). Wszystkie te nazwy oznaczają miasto znajdujące się nad rzeką Dźwiną. Ten ośrodek miejski stanowi ważny węzeł komunikacyjny łączący Rosję z Bałtykiem oraz Wilno z Petersburgiem.

W rezultacie złożonych uwarunkowań historyczno-politycznych Łatgalia jest prowincją polietniczną zamieszkaną przez przedstawicieli wielu religii (katolików, prawosławnych i protestantów). Do II wojny światowej skupiało się w miastach tej prowincji wielu Żydów. Równocześnie na jej terytorium znajdują się obszary etniczne łotewskie, polskie, rosyjskie i białoruskie. Zróżnicowania narodowościowe i religijne są cechą znamienną tej mało znanej w Polsce krainy geograficznej, leżącej na pograniczu wielu języków, narodów i religii. Dzięki mozaice etnicznej powstała wyjątkowa, niepowtarzalna specyfika kulturowa, niemająca sobie równej w Europie Środkowo-Wschodniej. Łatgalia powinna być wyjątkowo interesująca zwłaszcza dla Polaków, gdyż należała przez 211 lat (1561-1772) do Rzeczypospolitej

Prof. dr hab. Piotr EBERHARDT jest profesorem w Instytucie Geografii i Przestrzennego Zagospodarowania PAN w Warszawie. p.ebe@twarda.pan.pl 
i wiele pamiątek i obiektów zabytkowych przypomina o tym okresie historycznym. Ponadto przetrwała w tej peryferyjnej prowincji liczna mniejszość polska kultywująca pamięć swego pochodzenia i związków duchowych z Polską.

Łatgalia jest jedną z czterech prowincji historycznych, na które dzieli się współczesna Łotwa. Pozostałe to Liwlandia, Kurlandia i Semigalia1. Pod względem geograficznym, demograficznym, społecznym i ekonomicznym Łatgalia różni się od nich znacznie. Było to rezultatem specyficznych uwarunkowań historyczno-politycznych, które odzwierciedlity się w różnicach etniczno-kulturowych ${ }^{2}$. Pierwsza zasadnicza odmienność w stosunku do trzech pozostałych krain geograficznych Łotwy wynika z różnic religijnych. W Liwlandii, Semigalii i Kurlandii dominuje protestantyzm, natomiast łatgalscy Łotysze są w przeważającej części katolikami. Dialekt łatgalski odbiega znacznie od literackiego języka łotewskiego. Mieszkańcy centralnej i zachodniej Łotwy podlegali wpływom kultury niemieckiej, a mniejszość niemiecka odgrywała tam istotną rolę demograficzną i ekonomiczną. Na położonej bardziej peryferyjnie Łatgalii oddziaływały wpływy kultury i języka polskiego. Ze względu na swoje usytuowanie i długoletnią zależność od Rosji (1772-1916), a później ZSRR (1940-1941, 1944-1991) była również poddana rusyfikacji i demograficznej ekspansji żywiołu wschodniosłowiańskiego. Doprowadziło to w efekcie do tego, że na znaczącej części terytorium Łatgalii przebywa ludność języka i narodowości rosyjskiej. Podchodziła ona lekceważąco do państwowości łotewskiej i bliskie jej były interesy wielkomocarstwowe Moskwy.

Łatgalia miała również wyraźną specyfikę fizjograficzno-krajobrazową. Była w swoich granicach historycznych w miarę jednolitą jednostką geograficzną, odróżniającą się od swego otoczenia. Południową granicą Łatgalii był środkowy bieg Dźwiny. Sąsiaduje od wschodu z rosyjskim obwodem pskowskim i białoruskim obwodem witebskim. Na zachodzie i północnym-zachodzie graniczyła Łatgalia z tzw. Inflantami Szwedzkimi, czyli na południu z Semigalią, a na zachodzie z Liwlandią. Były to okręgi związane z miastami Walk (łot. Valka) i Kieś (łot. Cĕsis), a granicą były rzeki Pedeść (łot. Pededze) i Ewikszta (łot. Aiviekste). Po południowej stronie Dźwiny sąsiadował z Łatgalią powiat Iłukszta, należący do Zelanii, stanowiącej część historycznej Kurlandii. Po II wojnie światowej został on włączony do obwodu dyneburskiego i obecnie, niezbyt właściwie, traktowany jest jako integralna część Łatgalii.

\section{UWARUNKOWANIA HISTORYCZNE}

Całe terytorium współczesnej Łotwy, w tym również Łatgalię, pierwotnie zamieszkiwały wyłącznie plemiona bałtyckie. Na północy graniczyły one z ludami ugrofińskimi, z których

1 Polski historyk, autor interesującej książki o Łatgalii (Inflantach Polskich), w następujących słowach przedstawia historyczno-geograficzny podział ziem łotewskich: „Polska nazwa Inflanty (†ot. Vidzeme) pochodzi od fińsko-niemieckiej zbitki językowej Livland, czyli »Kraj Liwów« i odnosi się do terenów od ujścia Dźwiny (łot. Daugava), aż po południową Estonię, czyli dotyczy dzisiejszej północnej i środkowej Łotwy, łącznie z Rygą. Od roku 1660 ziemia ta, podobnie jak większa część Estonii, znalazła się pod panowaniem szwedzkim i stąd nosiła miano Inflant Szwedzkich. Od bałtyckiego plemienia Kurów (bądź Kurszów) pochodzi nazwa Kurlandia (łot. Kurzeme) i obejmuje zachodnią Łotwę od wybrzeża Bałtyku niemal do rzeki Lentawy (łot. Lielupe). Do tych terenów stosowano czasem (rzadko) określenie »Inflanty niemieckie«. Dalej na wschód, po lewej stronie Dźwiny od Mitawy (łot. Jelgava) do Dyneburga rozciąga się Semigalia (łot. Zemgale), która obejmuje też dawną Zelonie (łot. Selija). Kurlandia i Semigalia z Zelonią razem tworzyły w XVI-XVIII w. Księstwo Kurlandzkie, dlatego też obejmowane są często wspólną nazwą Kurlandia. W niemieckiej literaturze często natrafić można na zbitkę: "Liv-Est- und Kurland"" (K. Zajas 2008, s. 25-26). Na przedstawionym tle geograficznym cytowany autor opisuje dzieje Łatgalii, czyli historycznych Inflant Polskich.

2 Autor niniejszego artykułu opublikował dwie prace poświęcone totewskiej problematyce narodowościowej (P. Eberhardt 1997, 1998). Dotyczyły one całego terytorium współczesnego państwa łotewskiego. Z tego powodu zagadnienia odniesione do tematyki tatgalskiej były ujęte dość marginalnie. Zwalnia to autora od omawiania i interpretowania problemów ogólnołotewskich. 
wyodrębnił się naród estoński, na wschodzie byli zagrożeni ekspansją ludów słowiańskich, od południa zaś stykali się ze stosunkowo bliskimi im plemionami litewskimi. Okres izolacji zakończył się w końcu XII wieku. Za punkt zwrotny traktuje się 1158 rok, kiedy do ujścia Dźwiny dopłynęła grupa kupców z Lubeki. Od tego momentu rozpoczęła się penetracja niemiecka i w pewnym stopniu skandynawska (duńska). Stopniowo napływali osadnicy, którzy zakładali faktorie handlowe oraz rozpoczęli budować stałe siedziby. Rezultatem tej stopniowej kolonizacji była chrystianizacja. Powstało pierwsze biskupstwo w Rydze. W następnej fazie po akceptacji papieskiej powstał Zakon Kawalerów Mieczowych. Miał on w rzeczywistości na celu nie tyle działalność misyjną, ile podbój całego obszaru położonego od ujścia Niemna do Zatoki Fińskiej. Akcja ta była prowadzona w sposób zorganizowany i bardzo skuteczny. W miarę opanowywania nowych terenów budowano zamki obronne oraz tworzono ośrodki miejskie, w których osadzano osadników z Niemiec oraz rzadziej ludność tubylczą. Posiadłości ziemskie stały się własnością rycerstwa niemieckiego, w których zatrudniano miejscową ludność używającą dialektów prałotewskich. W pierwszym etapie opanowano Liwlandię i Semigalię, a dopiero w późniejszym czasie dalej położoną Łatgalię.

Korzystna koniunktura umożliwiająca szybki rozwój trwała aż do XV wieku. Następnie nastąpiły zmiany w ogólnej konstelacji politycznej. Trzy silne sąsiadujące państwa: Moskwa, Rzeczpospolita oraz Szwecja postanowity opanować ziemie położone nad Bałtykiem. Pretekstem do interwencji Rzeczypospolitej był zatarg Wielkiego Mistrza Zakonu Fürstenberga z arcybiskupem ryskim Wilhelmem. Król Polski Zygmunt August zmusił Wielkiego Mistrza do podporządkowania się Rzeczypospolitej. W odpowiedzi na polską ingerencje Moskwa i Szwecja przystąpiły do interwencji zbrojnej. Siły moskiewskie zostały wyparte, ale Szwecja zajęła obszar dzisiejszej Estonii. Pozostały obszar należący do Zakonu Kawalerów Mieczowych został w 1562 roku włączony do Rzeczpospolitej. Ostatni Wielki Mistrz Zakonu, Gotthard Kettler, stał się księciem Kurlandii i Semigalii i przeprowadził sekularyzację, która przyniosła istotne konsekwencje nie tylko religijne, ale i społeczne. Odmienny status polityczny uzyskały pozostałe obszary Inflant, które przyjęły nazwę Księstwa Inflanckiego (Zadzwińskiego), a w późniejszym czasie (od 1598 r.) zostały podzielone na województwa wendeńskie, dorpackie i parnawskie. Sytuacja polityczna była w miarę stabilna, aż do kolejnej wojny polsko-szwedzkiej (1621 r.), która zakończyła się pokojem w Altmarku (1629 r.). Rezultatem tego konfliktu militarnego była utrata przez Rzeczypospolitą 3/4 terytorium Inflant wraz z Rygą. W posiadaniu Rzeczpospolitej pozostała duża część woj. wendeńskiego, nazwanego woj. inflanckim; podzielona była na cztery części, które później przyjęły nazwę powiatów: dyneburskiego, rzeżyckiego, lucyńskiego oraz starostwa marienhauskiego. Stan ten trwał aż do drugiej wojny północnej, czyli najazdu Szwecji na Polskę (1655 r.). Zakończył się on pokojem oliwskim, który nie wprowadzit istotnych zmian granicznych. Ostatecznie Rzeczpospolita zrezygnowała z utraconych poprzednio Inflant Szwedzkich, zachowując Kurlandię oraz Inflanty Polskie. Ta pierwsza zachowała autonomię, co przyczyniło się do umocnienia protestantyzmu i pozycji niemieckich posiadaczy ziemskich. Natomiast Inflanty Polskie zostały już w pełni inkorporowane do Rzeczypospolitej i decyzją sejmu uzyskały w 1667 roku tytuł księstwa oraz status województwa (ryc. 1) .

3 Dzieje Inflant Polskich mają bogatą literaturę. Klasycznym i stale przypominanym dzietem jest opracowanie syna tej ziemi, wielkiego patrioty polskiego Gustawa Manteuffela, 1879), wznowione ostatnio (G. Manteuffel 2007). Przed samą II wojną światową ukazało się opracowanie przedstawiające ksztattowanie się stosunków politycznych między Polską a Inflantami (Polska 1939). Obszerną bibliografię na temat wczorajszej i dzisiejszej Łatgalii zamieszczono w pracach J. Kolbuszewskiego (1992), T. Paluczyńskiego (2003) oraz ło- 
Przynależność do Rzeczypospolitej przyniosła ze sobą nie tylko polonizację, ale przede wszystkim konsekwentnie realizowaną rekatolizację. Działalność ta zakończyła się spektakularnym sukcesem. Nie tylko szlachta, ale i chłopi łatgalscy stali się katolikami, a widocznym rezultatem tej zaprogramowanej akcji była budowa wielu świątyń katolickich. Pierwszy rozbiór Rzeczypospolitej przyniósł ostateczny kres Inflantom Polskim. Zostały one włączone do Cesarstwa Rosyjskiego 23 lata wcześniej niż protestancka Kurlandia. Pamięć o I Rzeczypospolitej przetrwała przez kilka pokoleń. Świadczą o tym wydarzenia związane z powstaniem listopadowym, a zwłaszcza z powstaniem styczniowym. Ówczesna szlachta wzięła w nim aktywny udział i poniosła bolesne skutki w postaci represji oraz konfiskat majątków.

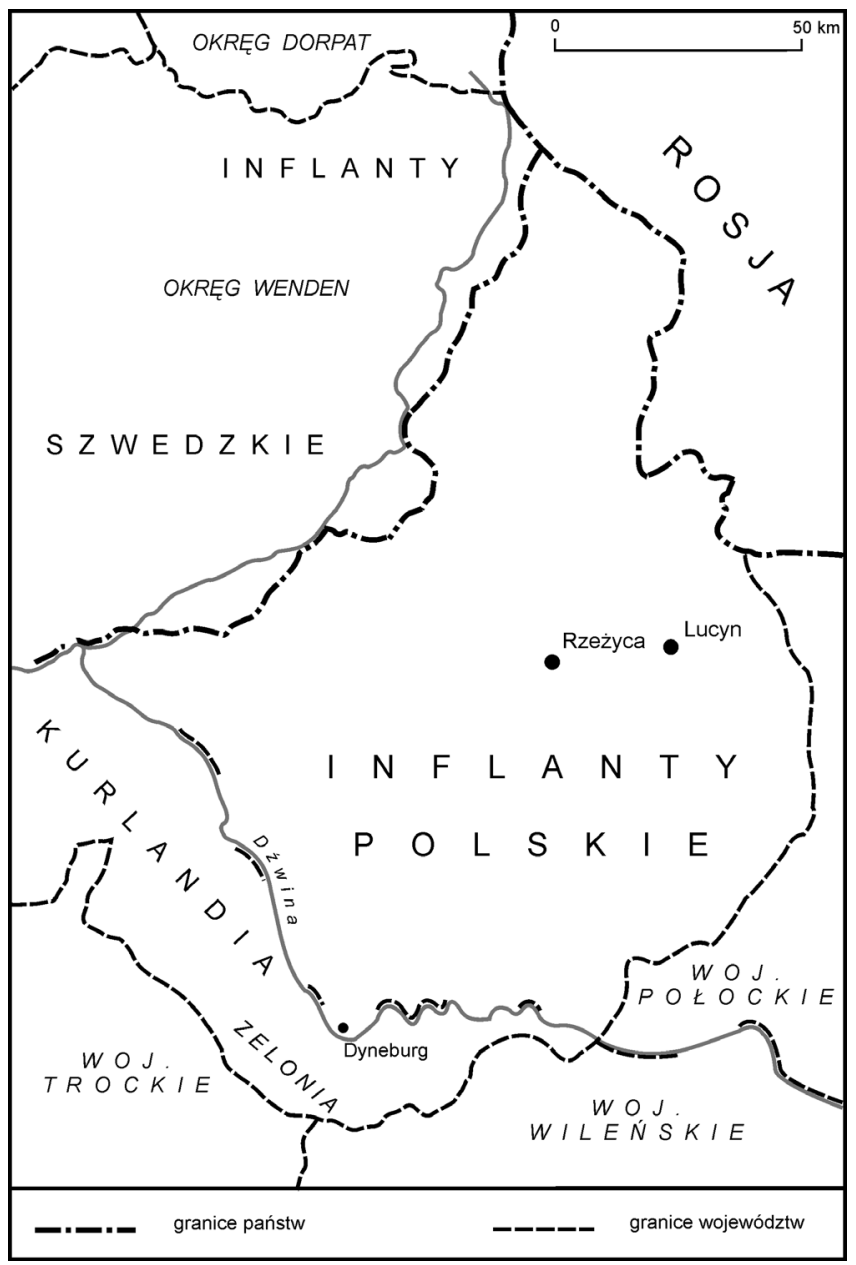

Ryc. 1. Inflanty Polskie (1561-1772).

Źr ó dło: Wielki Atlas Historyczny, wyd. Demart, Warszawa 2002, s. 48; Baltische Lande zu beginn der Nordischen krieges 1700, [w:] Staats- und Verwaltungs-Grenzen in Ostmitteleuropa, Verlag von r. Oldenbourg, 1954, München.

tewskiego historyka E. Jēkabsonsa (1993). Najwięcej jednak danych faktograficznych o dziejach Inflant Polskich oraz informacji bibliograficznych zawarto w książce współczesnego historyka polskiego (K. Zajas 2008). 
Włączenie Inflant Polskich czyli dzisiejszej Łatgalii do Rzeczypospolitej odcisnęło na tyle mocne piętno, że konsekwencje są widoczne do dnia dzisiejszego. Ponaddwustuletni okres przynależności do Rzeczypospolitej przyniósł nie tylko skutki polityczne, ale również długotrwałe reperkusje narodowościowe. Wynikały one z faktu, że miejscowa szlachta pochodzenia niemieckiego uzyskała przywileje polskie i ulegała stopniowej polonizacji. Potomkowie dawnych rodów niemieckich w ciągu kilku pokoleń stają się lojalnymi obywatelami Rzeczypospolitej, przyjmują język polski i wtapiają się w polskie społeczeństwo. Równocześnie napływają obdarowane dobrami ziemskimi rodziny szlacheckie z innych ziem Rzeczypospolitej. Przyspiesza to procesy polonizacyjne wśród warstw wyższych ${ }^{4}$. Bardziej złożona sytuacja etniczna była na obszarach wiejskich. Większa część ludności chłopskiej była rodowodu i języka łotewskiego. Na obrzeżach południowo-wschodnich Łatgalii przeważały natomiast dialekty języka białoruskiego. Jednocześnie do Dźwiny od strony południowo-zachodniej przylegał etniczny obszar litewski. Czynnikiem, który odegrał dużą rolę w kształtowaniu się oblicza etnicznego tego obszaru, była religia. Inflanty Polskie, w odróżnieniu od pozostałych ziem łotewskich, stały się katolickie. Umacniało to wpływy języka i kultury polskiej, która nie tylko oddziaływała na szlachtę, ale również na lud wiejski. Pojawienie się na terenie Łatgalii wsi polskich było spowodowane wieloma przyczynami. Pewną, choć niewielką rolę odegrały migracje Polaków, w tym drobnej szlachty, z etnicznych obszarów polskich. Nie były one jednak tak duże, aby wyjaśnić geneze powstania rejonów polskich w Łatgalii. Większą rolę odegrały procesy polonizacyjne wśród katolików rodowodu białoruskiego lub łotewskiego. Wpływ licznych duchownych pochodzenia polskiego oraz oddziaływanie całkowicie spolszczonej szlachty odegrało decydującą rolę w rozpowszechnieniu się języka polskiego wśród ludności wiejskiej, zamieszkującej tereny położone po północnej stronie Dźwiny ${ }^{5}$. Bardziej interesująca była postawa narodowościowa szlachty inflanckiej. Pełna lojalność wobec Rzeczypospolitej wiązała się z istnieniem swoistego kulturowego regionalizmu inflanckiego. Mieliśmy tu do czynienia z tym samym zjawiskiem, które występowało na obszarach Wielkiego Księstwa Litewskiego (gente Lithuanus - natione Polonus). Identyfikacja

W interesującym eseju poświęconym Inflantom Polskim o polonizacji warstw wyższych pisze polski historyk w sposób następujący: „O krzyżackim pochodzeniu rodów świadczyły już tylko brzmienia nazwisk: Broel-Platerów, Borchów, Korffów, Mohlów, Römerów, Roppów (dawniej Roppów von Kirburg), Denhofów (dawniej Dönhoffów) ... Thysenhusowie zmienili się w Tyzenhausów, Huelsenowie de Eckeln w Hylzenów, Rückowie w Rycków, a wreszcie w Ryków, Sybergowie à Wischling - w Zyberków (po małżeństwie ostatniej z Zyberków - Izabelli Heleny z Michałem Broel Platerem powstała w r. 1803 nowa rodzina: PlaterZyberk. W tej sytuacji przybywające do Inflant kolejne rodziny niemieckie nie były już w stanie utrzymać swej odrębności i szybko tonęły w „polskim morzu”. Stary ród rycerski z Nadrenii Weyss von Weyssenhoffów, osiedlający się tu w połowie XVII wieku, spolonizował się i odrzucił pierwszy człon nazwiska. Uległa też polskości pruska rodzina Reithenów: po przybyciu na Litwę w czasach Jana Kazimierza zmieniła nazwisko, kolejno, na Reuten, Reyten, wreszcie Reytan. Tymczasem już wcześniej, natychmiast po poddaniu Inflant Rzeczypospolitej, zaczęły tu osiadać rodziny polskie. W XVI w. przybyli z Lubelszczyzny Szadurscy herbu Ciołek, którzy dwieście lat później osiedli w majątku herbu Pusza w powiecie rzeżyckim (z rodziny tej pochodziła ceniona swego czasu poetka Stanisława Szadurska (zamęczona przez bolszewików w 1919 r. we własnym rodzinnym dworze). Z Ziemi Czerskiej przywędrowali w XVIII w. Bujniccy herbu Łabędź; z rodziny tej pochodził Kazimierz Bujnicki (1788-1878) - twórca „Rubonu” (starożytna nazwa Dźwiny), wileńskiego pisma poświęconego kulturze polskich Inflant oraz autor szeregu powieści i nowel odmalowujacych tutejsze życie polskie. Przybyli też na Inflanty Chodkiewicze, Czapscy, Soltanowie, Benisławscy, Skirmuntowie, Bujwidowie, a nawet Sobiescy herbu Janina" (A. Romanowski 1996, s. 6).

5 Procesy te były dość złożone, o czym świadczy przytoczony cytat ze wspomnianej już uprzednio książki: „Gdy pojęcie narodu ulega w XIX wieku redefinicji według nowych - etnicznych, językowych, wyznaniowych - kryteriów, kategoria „polskości' obejmuje nie tylko tutejszą arystokrację oraz napływową szlachtę, ale zaczyna odnosić się do wschodniołotewskich chłopów, uciekających przed rusyfikacją w objęcia katolickiego Kościoła i polskich panów. Należy przy tym pamiętać, że społeczność chłopską tworzyli tu nie tylko Łotysze, ale złotyszeni chłopi białoruscy, rosyjscy i litewscy, przybyli w poszukiwaniu lepszych warunków bytu, oraz chłopi polscy, których sprowadzili panowie obejmujący nowe majątki. Taki też jest tożsamościowy rodowód dzisiejszego Łatgalczyka, którego identyfikacja narodowa w niepodległej Łotwie błądzi pomiędzy elementem totewskim, białoruskim i polskim" (K. Zajas 2008, s. 147-148). 
z polskością łączyła się z podkreśleniem odmienności i odrębności historycznej szlachty inflanckiej ${ }^{6}$. Rody szlachty inflanckiej, po upadku Rzeczypospolitej, dochowały wierności kulturze i językowi polskiemu ${ }^{7}$ Świadczą o tym wydarzenia związane z powstaniami narodowymi. Natomiast włączenie Inflant do Cesarstwa Rosyjskiego zahamowało procesy polonizacyjne wsi latgalskiej.

\section{SYTUACJA NARODOWOŚCIOWA NA PRZELOMIE XIX I XX WIEKU}

Dla określenia w sposób skwantyfikowany liczebności i rozmieszczenia ludności w Łatgalii należy posłużyć się dokumentacją spisu rosyjskiego z 1897 roku. Starsze materiały zawierają mnóstwo informacji, ale mają charakter jedynie opisowy i uniemożliwiają ścisłe przedstawienie rozprzestrzeniania się i liczby Łotyszy, Rosjan czy Polaków. Przed dokonaniem analizy statystycznej, odniesionej do Łatgalii, należy określić zasięg przestrzenny interesującego nas obszaru. W celu zapewnienia porównywalności terytorialnej ustanowiono stałą jednostkę odniesienia przestrzennego. Będzie to obszar zawarty w dzisiejszych lub międzywojennych granicach państwa łotewskiego.

Pierwszy nowoczesny spis rosyjski z 1897 roku uwzględnit dwa kryteria odniesione do etniczności jednostki: język oraz religię. Wyznacznik językowy traktowany był przez demografów zazwyczaj jako miernik określający narodowość, albowiem przy ograniczonej samoidentyfikacji warstwy chłopskiej język często - choć nie zawsze - pokrywał się z narodowością. Przyjmując takie założenie, dopuszczamy się pewnej nieścisłości, ponieważ na terenach takich jak Łatgalia w powszechnym użyciu były dwa lub trzy języki, nie licząc miejscowych dialektów. W takiej sytuacji w zależności od warunków politycznych duża grupa ludności wiejskiej składała deklarację językową w sposób koniunkturalny.

Historyczne Inflanty Polskie zostały podzielone przez władze carskie na trzy jednostki administracyjne, „ujezdy” (powiaty): Dyneburg, Rzeżyca oraz Lucyn. Wszystkie one należały do guberni witebskiej (ryc. 2). Spis rosyjski odnotował na tym obszarze 501,6 tys. mieszkańców, z których połowa zadeklarowała jako swój język ojczysty język łotewski. Duża część ludności posługiwała się językami słowiańskimi (rosyjskim, białoruskim i polskim). Stanowiła ta grupa językowa 41,4\% ogółu mieszkańców, w tym w powiecie Dyneburg przeważała ona nad ludnością łotewskojęzyczną. W samym mieście Dyneburg przeważała ludność podchodzenia żydowskiego (tab. 1).

Regionalizm inflancki ujawnit się w sposób szczególny u wielu pisarzy pochodzących ze znanych rodów ziemiańskich (Manteuffel 1879).

7 Wielu polskich działaczy politycznych i znanych pisarzy pochodzących z Inflant Polskich zajmowało się w ciągu ostatnich 150 lat kulturą tego regionu. Piśmiennictwo polskie w tej dziedzinie jest bardzo bogate. Wiele informacji z tego zakresu znajduje się w interesującym eseju K. Dybciaka (1993, s. 75-102), w opracowaniu zbiorowym (Kultura, 1994) oraz w książce A. Durejko (2001).

8 Pisze o tym współczesny historyk łotewski w sposób następujący: „Zauważono niezdecydowanie części mieszkańców Łatgalii i powiatu iłtuksztańskiego odnośnie do swojej narodowości. Wybór ten zależał od odpowiedniej agitacji. Były nawet takie wypadki, że w jednej gminie w ciągu 5 lat liczba mieszkańców narodowości polskiej zmieniała się od kilku do kilkudziesięciu tysięcy. Różnica była tak duża, że wykorzystywano ją w celach propagandowych w nacjonalistycznych kręgach łotewskich. W kilku gminach mieszkańcy nie mogli dokonać wyboru między narodowością polską, białoruską i łotewską. Język używany na co dzień nie stanowił tu odpowiedniego kryterium, bo często składały się nań wyrazy pochodzące ze wszystkich trzech języków narodowych" (E. Jēkabsons 1993, s. 34-35). 
Tabela 1. Struktura językowa ludności Ziemi Łatgalskiej w 1897 roku.

\begin{tabular}{|c|c|c|c|c|c|c|c|c|}
\hline \multirow{3}{*}{ Język } & \multirow{2}{*}{\multicolumn{2}{|c|}{$\begin{array}{c}\text { Liczba } \\
\text { mieszkańców }\end{array}$}} & \multicolumn{6}{|c|}{ w tym w powiecie } \\
\hline & & & \multicolumn{2}{|c|}{ Dyneburg } & \multicolumn{2}{|c|}{ Rzeżyca } & \multicolumn{2}{|c|}{ Lucyn } \\
\hline & w tys. & $w \%$ & w tys. & $w \%$ & $w$ tys. & $w \%$ & w tys. & $w \%$ \\
\hline Łotewski & 253,7 & 50,6 & 92,5 & 39,0 & 78,9 & 57,8 & 82,3 & 64,2 \\
\hline Rosyjski & 77,9 & 15,5 & 36,1 & 15,2 & 32,6 & 23,9 & 9,2 & 7,2 \\
\hline Białoruski & 66,4 & 13,2 & 32,7 & 13,8 & 7,4 & 5,4 & 26,3 & 20,5 \\
\hline Żydowski & 63,9 & 12,7 & 47,5 & 20,0 & 10,1 & 7,4 & 6,3 & 4,9 \\
\hline Polski & 30,9 & 6,2 & 21,6 & 9,1 & 6,5 & 4,8 & 2,8 & 2,2 \\
\hline Niemiecki & 4,7 & 0,9 & 4,0 & 1,7 & 0,4 & 0,3 & 0,3 & 0,2 \\
\hline Litewski & 1,4 & 0,3 & 0,9 & 0,5 & 0,2 & 0,1 & 0,3 & 0,2 \\
\hline Inny & 2,7 & 0,6 & 1,7 & 0,7 & 0,3 & 0,3 & 0,7 & 0,6 \\
\hline Ogółem & 501,6 & 100,0 & 237,0 & 100,0 & 136,4 & 100,0 & 128,2 & 100,0 \\
\hline
\end{tabular}

Źr ó d to: Piervaja vsjeobščaja pieriepis nasielienija Rossijskoj Imperii 1897 g, T. V, Vitebskaja Gubernija, s. 54155, Sankt Petersburg 1899.

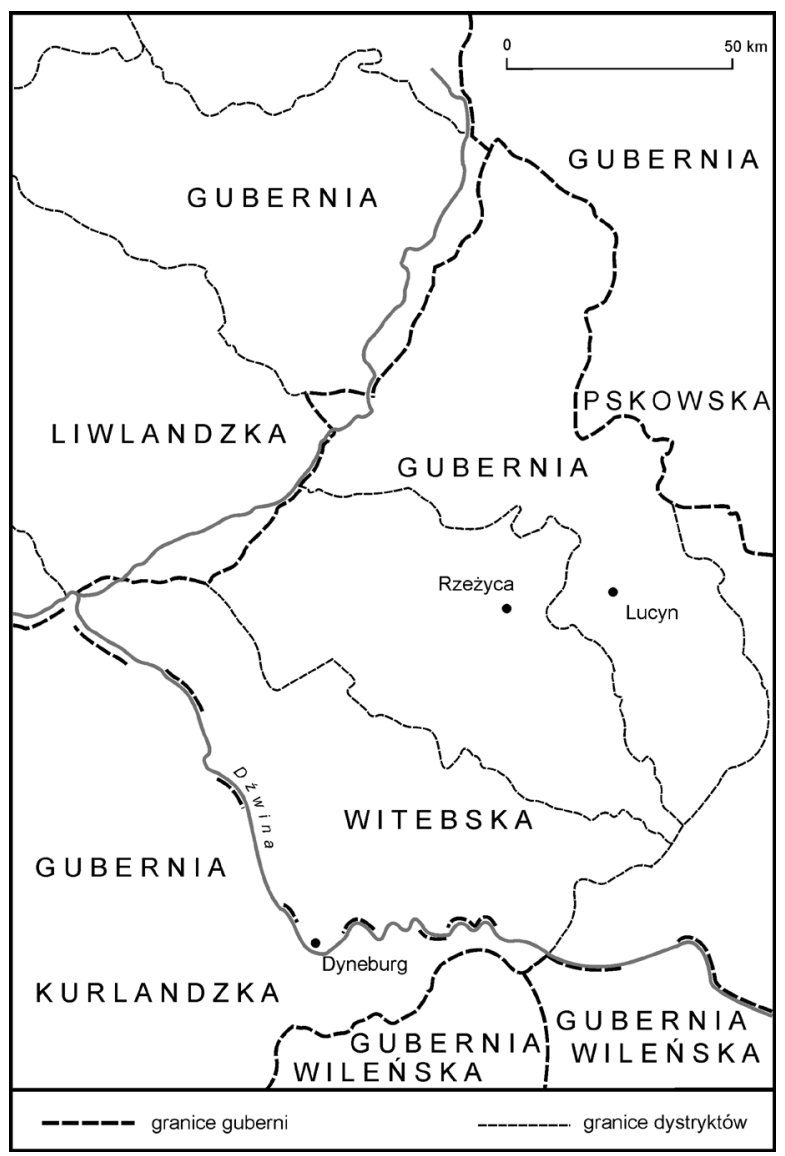

Ryc. 2. Łatgalia w granicach Cesarstwa Rosyjskiego (1772-1916).

Źr ó dło: Baltische Lande, Livland Estland Kurland 1783, [w:] Staats- und Verwaltungs-Grenzen in Ostmitteleuropa, Verlag von r. Oldenbourg, 1954, München. 
Spis ujawnit w trzech powiatach dawnych Inflant Polskich 30,9 tys. osób, które zadeklarowały język polski. W pobliskim powiecie Iłłukszta położonym na lewym brzegu Dźwiny, ale należącym do historycznej Kurlandii, dodatkowo 11,4 tys. spisywanych też podało język polski jako swój język ojczysty. Na tym obszarze ziemiaństwo, jak już wspomniano, składało się z Polaków, ale było ono mało liczne, chociaż pozycja społeczna ziemian była wysoka. Wynika więc z tych danych, że wielu chłopów przyznawało się do polskości. Pochodzenie tej ludności było kwestią kontrowersyjną i powodowało różnice poglądów między badaczami totewskimi, rosyjskimi, białoruskimi i polskimi. Demografowie totewscy uważali ich za spolonizowanych Łotyszy, białoruscy i rosyjscy za skatolicyzowanych Białorusinów. Badacze polscy natomiast uważali, jak wspomniano, że była to ludność powstała ze zmieszania się ludności rodowodu łotewskiego i białoruskiego z napływową ludnością polską, która, podlegając wpływom polskojęzycznego Kościoła katolickiego oraz polskiego ziemiaństwa, przyjęła polski język i polską świadomość narodową. Władze rosyjskie organizujące spis ludności starały się ich liczebność zminimalizować.

Oficjalne dane spisowe zostały zweryfikowane przez polskiego badacza E. Maliszewskiego (1922, s. 12). Według jego szacunków liczebność Polaków w 1897 roku wynosiła: w powiecie dynenburskim - 43,2 tys., lucyńskim - 15,9 tys., rzeżyckim - 10,2 tys. Razem w trzech powiatach według tego autora było 69,3 tys. Polaków. W innej z polskich prac spotykamy jeszcze inne szacunki odniesione do liczby Polaków, mianowicie w powiecie dynenburskim miało być 55,0 tys. ludności polskiej (19,2\% ogółu ludności), w lucyńskim - 19,2 tys. (13,4\%), w rzeżyckim - 13,6 tys. (7,6\% ogółu ludności). Łącznie Polaków w trzech powiatach Łatgalii miało być 86,8 tys. (Keller 1920, s. 5).

W odróżnieniu od danych językowych, które budzą istotne kontrowersje statystyczne i merytoryczne, drugie kryterium zastosowane w spisie, wskazujące na etniczność jednostki, mianowicie: przynależność religijna, stanowiło informację w pełni wiarygodną (tab. 2).

Tabela 2. Struktura religijna ludności Ziemi Łatgalskiej w 1897 roku.

\begin{tabular}{|c|c|c|c|c|c|c|c|c|}
\hline \multirow{3}{*}{ Wyznanie } & \multirow{2}{*}{\multicolumn{2}{|c|}{$\begin{array}{c}\text { Liczba } \\
\text { mieszkańców }\end{array}$}} & \multicolumn{6}{|c|}{ w tym w powiecie } \\
\hline & & & \multicolumn{2}{|c|}{ Dynenburg } & \multicolumn{2}{|c|}{ Rzeżyca } & \multicolumn{2}{|c|}{ Lucyn } \\
\hline & w tys. & w \% & w tys. & $w \%$ & w tys. & w \% & w tys. & w \% \\
\hline Rzymskokatolickie & 285,9 & 57,0 & 117,3 & 49,5 & 87,3 & 64,0 & 81,3 & 63,4 \\
\hline Judaistyczne & 64,3 & 12,8 & 47,8 & 20,1 & 10,2 & 7,5 & 6,3 & 4,9 \\
\hline Prawosławne & 52,3 & 10,4 & 22,5 & 9,5 & 4,6 & 3,4 & 25,2 & 19,7 \\
\hline Protestanckie & 37,4 & 7,5 & 22,5 & 9,5 & 2,6 & 1,9 & 12,3 & 9,6 \\
\hline Staroobrzędowcy & 60,6 & 12,1 & 26,0 & 11,0 & 31,5 & 23,0 & 3,1 & 2,4 \\
\hline Inne & 1,1 & 0,2 & 0,9 & 0,4 & 0,2 & 0,2 & - & 0,0 \\
\hline Ogółem & 501,6 & 100,0 & 237,0 & 100,0 & 136,4 & 100,0 & 128,2 & 100,0 \\
\hline
\end{tabular}

Źr ó d ło: Piervaja vsjeobščaja pieriepis nasielienija Rossijskoj Imperii 1897 g., T. V, Vitebskaja Gubernija, s. 54155, Sankt Petersburg 1899.

Przeważała, jak to można było przewidzieć, ludność katolicka obejmująca Łotyszy i Polaków. Do prawosławia należeli napływowi Rosjanie oraz Białorusini. Interesującą grupą etniczną byli rosyjscy staroobrzędowcy. Żyli oni w izolacji od otoczenia, kultywując swoją wiarę i obyczaje przywiezione z głębi Rosji. Działali, podobnie jak prawosławni, dezintegrująco na miejscową ludność pochodzenia łotewskiego lub polskiego. Niewielka grupa miejscowych bardziej zasymilowanych Żydów przyznawała się do języka rosyjskiego. 
Lata I wojny światowej przynosiły Ziemi Łatgalskiej duże straty demograficzne. Władze rosyjskie dokonały ewakuacji części ludności. W trakcie walk frontowych duże obszary, w wyniku przechodzenia frontu, uległy dewastacji. Po rewolucji bolszewickiej i klęsce kajzerowskich Niemiec nastąpiło w listopadzie 1918 roku proklamowanie utworzenia niepodległej Republiki Łotewskiej. Przez pewien czas ważyły się losy byłych Inflant Polskich, ale ostatecznie zostały one przyłączone do Łotwy ${ }^{9}$. Ludność miejscowa bez względu na narodowość uzyskała obywatelstwo totewskie.

Programowym założeniem władz niepodległego państwa było ujednolicenie narodowościowe kraju i umocnienie w nim żywiołu łotewskiego. Zwłaszcza chodziło o unicestwienie siły ekonomicznej miejscowego ziemiaństwa, które w Łatgalii było polskie, zaś na pozostałym obszarze Łotwy żyło w orbicie języka i kultury niemieckiej. Kierując się tą nadrzędną przesłanką, sejm łotewski podjął decyzję o przeprowadzeniu reformy rolnej i wywłaszczeniu bogatych posiadaczy ziemskich. Według danych sprzed I wojny światowej w rękach polskich właścicieli znajdowało się wówczas w powiecie dyneburskim 68,4\%, w powiecie rzeżyckim - 57,8\% oraz lucyńskim 39,3\% areału ziemi (K. Keller 1920, s. 13-14).

Reforma agrarna została przeprowadzona na Łotwie w sposób rygorystyczny i bezwzględny ${ }^{10}$. Pomimo początkowych zapewnień, właściciele nie uzyskali odszkodowania za skonfiskowaną ziemię i majątki. Rozparcelowaną polską wielkoobszarową własność ziemską głównie przekazano chłopom narodowości łotewskiej. Wiele pałaców zostało przekształconych w obiekty użyteczności publicznej (np. szkoły). Niektóre z nich uległy dewastacji i do dnia dzisiejszego nie zostały odbudowane. Właściciele byli w zasadzie zmuszeni opuścić swoje siedziby rodowe, które były ostoją polskości. Polskojęzyczna służba folwarczna o dość słabo wyrobionej świadomości narodowej została podporządkowana miejscowej administracji łotewskiej. Jedynym dla niej wsparciem były polskojęzyczne parafie katolickie, które stopniowo przejmowali duchowni pochodzenia łotewskiego.

Młode państwo łotewskie prowadziło konsekwentną politykę zmierzającą do asymilacji mniejszości narodowych. Następowała zaplanowana łotyszyzacja (lettonizacja) szkolnictwa oraz eliminowanie wszelkich organizacji i stowarzyszeń polsko- i niemieckojęzycznych. Wobec mniejszości rosyjskiej prowadzono politykę bardziej liberalną.

Terytorialny podział administracyjny został zachowany. Wprowadzono nazewnictwo łotewskie. W stosunku do rosyjskich rozgraniczeń administracyjnych wystąpiły jedynie niewielkie modyfikacje. Były one spowodowane koniecznością ustalenia nowej granicy politycznej między Łotwą a bolszewicką Rosją. Nie tylko całe byłe Inflanty Polskie zostały włączone do państwa łotewskiego, ale udało się przyłączyć niewielkie obszary z byłej guberni pskowskiej. Utworzono nowy powiat o łotewskiej nazwie Jaunlatgale (o słowiań-

9 W wyzwoleniu Łatgalii od okupacji bolszewickiej wzięły udział oddziały polskie liczące 30 tys. żołnierzy pod dowództwem E. Rydza Śmigłego. Zdobyły one wówczas Dyneburg (3 | 1920). Przed wojną na cmentarzu, gdzie pochowano 297 polskich żołnierzy postawiono duży krzyż. Został on zdemontowany przez władze sowieckie i następnie odtworzony w 1992 roku.

10 W książce polskiego autora podane są imiennie majątki polskie, które uległy parcelacji, a mianowicie na przykład: „Michała Reutta w Warkowie (liczący w 1905 r. 14166 ha, rodziny Plater-Zyberków: Andrzeja w Kołupie (11 806 ha), Henryka w Niegalu (6080), Teofila w Wabolu (3260), Adama w Kirupie (2632), Jana w Liksnie (2509), Piotra w Ambelmujży (1706) i Henryka w Pelczy (1665), rodziny Broel-Platerów: Marii w Krasławiu (4422), Eugeniusza i Michała z Ludwijampolu (2851) i Dobromyślu (1859) i Michała w Kombule 91363), Marii Zabiełty w Marienhausie (49 300), Izabeli Orłowskiej w Maly (19475), Teresy w Brochowie (7626), Stanistawy Szadurskiej w Dobropolu (4779), Moniki Benistawskiej w Andrepnie i Zelenpolu (6847), Romerów w Jampolu (3554) itd. (J. Albin 1993, s. 39). 


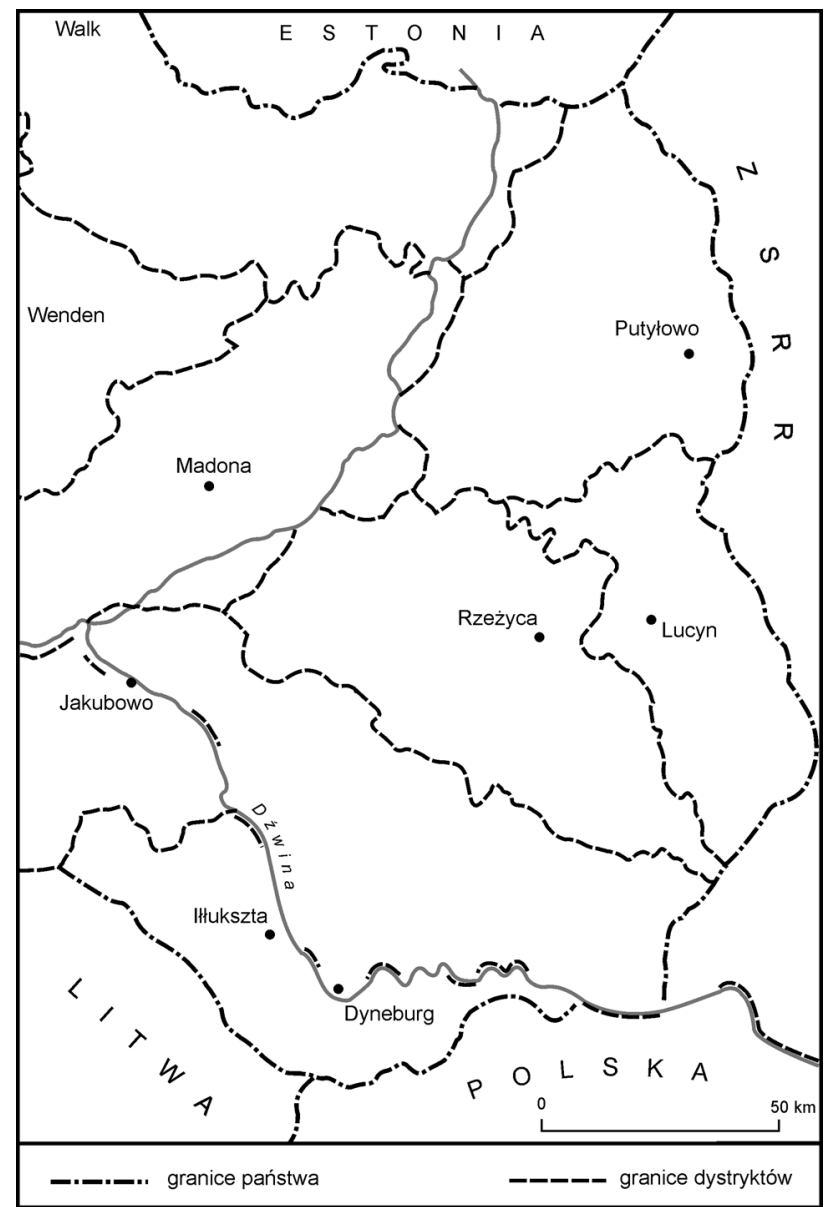

Ryc. 3. Łatgalia w granicach Łotwy (1920-1940).

Żr ó dło: Baltische Lande, Die Freistaaten Estland und Lettland 1920-40, [w:] Staats- und Verwaltungs-Grenzen in Ostmitteleuropa, Verlag von r. Oldenbourg, 1954, München.

skiej nazwie Putyłowo) (ryc. 3). Wschodnia część tego powiatu, wraz z miastem, była w granicach Łotwy aż do 1940 roku, a następnie została inkorporowana do ZSRR. Nie miało to jednak dużego znaczenia statystycznego. W okresie międzywojennym na Łotwie przeprowadzano co pięć lat spis ludności (1920, 1925, 1930, 1935), w którym uwzględniano dwa kryteria etniczności: narodowość oraz wyznanie religijne. Rezultaty były publikowane według prowincji („apgali”) oraz powiatów („aprinki”). Przyjęto do niniejszej analizy wyniki spisu z 1930 roku, gdy sytuacja w kraju była ustabilizowana, a przy władzy w kraju stały siły w miarę demokratyczne, co sprzyjało wiarygodności spisu. Porównanie danych spisowych z 1930 roku z przytoczonymi uprzednio danymi ze spisu rosyjskiego z 1897 roku daje możliwość ukazania ewolucji stosunków narodowościowych. Zgodnie z przewidywaniami, nastąpiło wzmocnienie żywiołu łotewskiego z 50,6 do 56,9\%. Przyznawanie się do języka dominującego jest zazwyczaj preferowane na obszarach mieszanych narodowościowo. 
Przy niewielkim bezwzględnym przyroście ludności polskiej nastąpiło skokowe obniżenie liczby ludności przyznającej się do języka lub narodowości białoruskiej (1897 r. - 66,4 tys.; 1930 r. - 22,3 tys.). Można przypuszczać, że była to ludność posługująca się językiem białoruskim, lecz wyznania katolickiego. Miała ona słabo wykształconą świadomość narodową i często w sposób przypadkowy lub koniunkturalny wybierała narodowość białoruską, polską lub łotewską. Przy wyborze tej ostatniej często identyfikowała narodowość z obywatelstwem. Pomimo przewagi ludności łotewskiej nadal Łatgalia odznaczała się w okresie międzywojennym niezmiernie złożoną strukturą narodowościową (tab. 3).

Tabela 3. Struktura narodowościowa ludności Ziemi Łatgalskiej w 1930 roku.

\begin{tabular}{|l|c|c|c|c|c|c|c|c|c|c|}
\hline \multirow{2}{*}{ Narodowość } & \multirow{2}{*}{$\begin{array}{c}\text { Liczba } \\
\text { mieszkańców }\end{array}$} & \multicolumn{9}{|c|}{ w tym w powiecie } \\
\cline { 2 - 12 } & w tys. & w $\%$ & w tys. & w \% & w tys. & w \% & w tys. & w \% & w tys. & w \% \\
\hline Łotewska & 307,9 & 56,9 & 110,9 & 54,8 & 89,4 & 62,0 & 52,2 & 57,9 & 55,4 & 53,1 \\
\hline Rosyjska & 148,5 & 27,4 & 38,5 & 19,0 & 40,2 & 27,9 & 25,1 & 27,8 & 44,7 & 42,9 \\
\hline Polska & 29,6 & 5,5 & 19,1 & 9,4 & 5,3 & 3,7 & 4,5 & 5,0 & 0,7 & 0,7 \\
\hline Żydowska & 28,7 & 5,3 & 17,9 & 8,8 & 6,0 & 4,2 & 3,3 & 3,7 & 1,5 & 1,4 \\
\hline Białoruska & 22,3 & 4,1 & 13,5 & 6,7 & 2,7 & 1,8 & 4,8 & 5,3 & 1,3 & 1,2 \\
\hline Niemiecka & 1,1 & 0,2 & 0,8 & 0,4 & 0,1 & 0,1 & 0,1 & 0,1 & 0,1 & 0,1 \\
\hline Litewska & 1,0 & 0,2 & 0,6 & 0,3 & 0,1 & 0,1 & 0,1 & 0,1 & 0,2 & 0,2 \\
\hline Inna & 2,0 & 0,4 & 1,1 & 0,6 & 0,4 & 0,2 & 0,1 & 0,1 & 0,4 & 0,4 \\
\hline Ogółem & 541,1 & 100,0 & 202,4 & 100,0 & 144,2 & 100,0 & 90,2 & 100,0 & 104,3 & 100,0 \\
\hline
\end{tabular}

Żród to: Troisième recenssement de la population en Lattonie en 1930. T. II. Riga 1930.

Najbardziej złożona sytuacja miała miejsce w powiecie dyneburskim, a zwłaszcza w jego stolicy. Było to miasto usytuowane wówczas w pobliżu granicy z Polską, Litwą i ZSRR. Uległo ono ekonomicznej degradacji, gdyż straciło swoje znaczenie komunikacyjne jako jeden z ważniejszych węzłów transportowych imperium rosyjskiego. Dyneburg stał się prowincjonalnym miastem położonym na peryferiach małego państwa. Miasto to zawsze było usytuowane w strefie krzyżowania się obszarów etnicznych: łotewskich, białoruskich, polskich, rosyjskich i litewskich. Z tego też powodu skład narodowościowy Dyneburga zawsze był daleki od jednorodności. Heterogeniczność językowa, narodowa i religijna była jego cechą najbardziej znamienną. Na przykład w mieście liczącym w 1930 roku 43,2 tys. mieszkańców do narodowości łotewskiej przyznawało się 27,0\%, żydowskiej - 26,9\%, polskiej - 20,8\%, rosyjskiej - 19,5\% ogółu mieszkańców. Można sądzić, że mało było miast w Europie, w których proporcje między czterema grupami narodowościowymi były tak ilościowo wyrównane, a najliczniejsza z nich obejmowała zaledwie 27,0\% ogółu ludności. Na obszarach otaczających Dyneburg, każda w zasadzie wieś miała swoją odrębną specyfikę językową, narodowościową i wyznaniową. Dla ukazania tego zróżnicowania zostaną przedstawione dane narodowościowe dla powiatu dyneburskiego według jednostek gminnych, które zazwyczaj obejmowały po kilka wsi (tab. 4). 
Tabela 4. Dane narodowościowe dla powiatu dyneburskiego według jednostek gminnych.

\begin{tabular}{|c|c|c|c|c|c|c|c|c|c|}
\hline \multirow{2}{*}{ Lp. } & \multicolumn{2}{|c|}{ Nazwa miast i gmin } & \multirow{2}{*}{$\begin{array}{l}\text { Liczba } \\
\text { ludności } \\
\text { w tys. }\end{array}$} & \multicolumn{6}{|c|}{ Narodowość (w \%) } \\
\hline & totewska & polska* & & Łotysze & Rosjanie & Polacy & Żydzi & Białorusini & inni \\
\hline 1. & Daugavpils & Dyneburg & 43226 & 27,0 & 19,5 & 20,8 & 26,9 & 2,3 & 3,5 \\
\hline 2. & Kraslavas & Krasław & 4283 & 16,5 & 12,4 & 29,6 & 36,2 & 4,1 & 1,2 \\
\hline 3. & Litvanu & Liwenhof & 3219 & 60,5 & 4,3 & 2,7 & 31,4 & 0,0 & 1,1 \\
\hline 4. & Krustpils & Kryżbork & 3213 & 53,4 & 5,3 & 1,6 & 35,8 & 1,8 & 2,1 \\
\hline 5. & Preilu & Prele & 1747 & 23,3 & 17,3 & 6,4 & 51,1 & 0,7 & 1,2 \\
\hline I & \multicolumn{2}{|c|}{ Ogółem miasta } & 55688 & 29,5 & 17,2 & 18,9 & 29,5 & 2,2 & 3,0 \\
\hline 1. & Aiviekstes & & 1579 & 90,1 & 5,3 & 0,2 & 0,3 & 3,7 & 0,4 \\
\hline 2. & Asunes & Osuń & 6588 & 91,9 & 3,5 & 1,7 & 0,3 & 1,7 & 0,9 \\
\hline 3. & Aulejas & Aula & 6392 & 52,7 & 24,9 & 4,0 & 0,1 & 17,7 & 0,6 \\
\hline 4. & Dagdas & Dagda & 6856 & 62,6 & 15,5 & 10,2 & 9,7 & 1,0 & 1,0 \\
\hline 5. & Izvaltas & Użwałd & 8789 & 50,3 & 46,0 & 1,3 & 0,1 & 2,0 & 0,3 \\
\hline 6. & Jasmuizes & Jasmujża & 6890 & 82,6 & 9,8 & 7,2 & 0,1 & 0,1 & 0,2 \\
\hline 7. & Kalupes & Kołup & 5626 & 84,0 & 13,5 & 1,7 & 0,3 & 0,1 & 0,4 \\
\hline 8. & Kapinu & Kapino & 12069 & 51,5 & 26,2 & 10,3 & 0,8 & 10,6 & 0,6 \\
\hline 9. & Kraslavas & Krasław & 7220 & 77,2 & 3,1 & 13,1 & 0 & 5,6 & 1,0 \\
\hline 10. & Krustpils & Kryżbork & 6194 & 94,7 & 2,8 & 0,8 & 0,1 & 1,2 & 0,4 \\
\hline 11. & Liksnas & Liksna & 10531 & 81,7 & 15,9 & 1,5 & 0,1 & 0,6 & 0,2 \\
\hline 12. & Livanu & Liwenhof & 7121 & 80,0 & 18,7 & 1,0 & 0,1 & 0,1 & 0,1 \\
\hline 13. & Naujenes & Józefowo & 8128 & 45,9 & 44,8 & 7,8 & 0,0 & 1,3 & 0,2 \\
\hline 14. & Piedrujas & Piedrujsk & 6384 & 16,7 & 1,9 & 9,6 & 3,2 & 68,2 & 0,4 \\
\hline 15. & Preilu & Prele & 9023 & 73,7 & 24,1 & 1,6 & 0,1 & 0,4 & 0,1 \\
\hline 16. & Pustinas & Pustyń & 3919 & 24,0 & 5,1 & 19,1 & 0,2 & 51,4 & 0,2 \\
\hline 17. & Rudzetu & & 3297 & 86,0 & 10,6 & 3,2 & 0,1 & 0,1 & 0,0 \\
\hline 18. & Skaitas & Skajsty & 6730 & 44,5 & 3,9 & 20,5 & 0,3 & 27,5 & 3,3 \\
\hline 19. & Ungurmuizas & Ungermuzja & 3329 & 73,0 & 14,9 & 0,1 & 0,5 & 11,4 & 0,1 \\
\hline 20. & Varkavas & Warków & 7444 & 81,4 & 15,4 & 2,5 & 0,4 & 0,0 & 0,3 \\
\hline 21. & Vipes & & 1825 & 75,8 & 23,5 & 0,2 & 0,0 & 0,2 & 0,3 \\
\hline 22. & Visku & Wyszki & 10792 & 41,1 & 47,6 & 4,8 & 4,9 & 1,4 & 0,2 \\
\hline II & Ogółem & gminy & 146696 & 64,4 & 19,7 & 5,9 & 1,1 & 8,4 & 0,5 \\
\hline III & Ogó & tem & 202384 & 54,8 & 19,0 & 9,4 & 8,9 & 6,7 & 1,2 \\
\hline
\end{tabular}

Źr ó dło: Trešã Tautas Skaitišana Latvija, 1930 goda. Valts Statistikã Parvalde. Riga 1930. Dla trzech gmin nie zdołano ustalić używanych odpowiedników nazw polskich.

* Odpowiedniki nazw polskich zostały określone na podstawie oryginalnych polskich map topograficznych wydawanych w okresie międzywojennym. Ze względu na wyraźny fakt, że niektóre z nazw brzmią sztucznie, nie są zgodne z duchem języka polskiego, przypuszczalnie miały miejsce błędy lub zniekształcenia wywołane istnieniem równorzędnych odpowiedników w języku łotewskim, niemieckim, litewskim lub białoruskim. Autor nie był w stanie tego zweryfikować. Ta uwaga dotyczy nie tylko powyższej tabeli. 
W kilku gminach położonych po północnej stronie Dźwiny odsetek ludności polskiej dochodził do kilkunastu procent. Najwięcej jej było w gminach Skajsty i Pustyn. Jeszcze wyższy udział Polaków występował we wsiach położonych po południowej stronie Dźwiny w powiecie Iłukszta, należącym do historycznej Kurlandii (Zelani) ${ }^{11}$.

Działalność organizacyjna Polaków w Łatgalii została już wszechstronnie omówiona w literaturze przedmiotu (J. Albin 1993). Warto jedynie przypomnieć, że bardzo aktywnie działał Związek Polaków na Łotwie, który miał wiele placówek terenowych. Istniało szkolnictwo polskie posiadające znaczną autonomię językową. Funkcjonowało harcerstwo polskie oraz liczne stowarzyszenia propagujące język i kulturę polską. Dzięki temu w okresie okupacji hitlerowskiej Armia Krajowa była w stanie stworzyć tu odpowiednie ekspozytury dywersyjne.

Okres międzywojenny odegrał olbrzymią rolę w tworzeniu nowoczesnego narodu łotewskiego. Istnienie własnego państwa, zapewnienie językowi łotewskiemu - po raz pierwszy w historii - uprzywilejowanej pozycji, rozwój literatury i kultury narodowej miały brzemienne znaczenie. Bez tego dwudziestolecia naród łotewski nie byłby w stanie przetrwać późniejszej, długotrwałej okupacji sowieckiej i po rozpadzie ZSRR reaktywować szybko nowe państwo. Pamięć o własnym niepodległym i sprawnie zorganizowanym państwie była tym światopoglądowym spoiwem, na którym można byłoby odbudować na początku lat 90. XX wieku suwerenną Łotwę.

\section{SYTUACJA NARODOWOŚCIOWA W OKRESIE SOWIECKIM}

Łatgalia, podobnie jak cała Łotwa, została w 1940 roku przyłączona do ZSRR. Bezpośrednio po zajęciu kraju NKWD dokonało akcji represyjnej skierowanej przeciwko wszelkim organizacjom "burżuazyjnym”. W ramach nasilającego się terroru likwidowano faktycznych i potencjalnych przeciwników nowej władzy sowieckiej. Dokonywano masowych aresztowań, rozstrzeliwań i deportacji. Agresja hitlerowskich Niemiec na ZSRR zmieniła diametralnie sytuację. Łatgalia została zajęta przez nowych okupantów. Rozpoczęła się eksterminacja Żydów. Stosunek Niemców do pozostałych narodowości był selektywny. Ludność słowiańska była gorzej traktowana od rdzennych Łotyszy. Wraz z ponownym wkroczeniem armii sowieckiej rozpoczęła się nowa fala represji i prześladowań. Działała antykomunistyczna partyzantka, która wywołała w odpowiedzi brutalną akcje pacyfikacyjną, a następnie deportacje ludności w głąb ZSRR. Równocześnie zaczęła napływać ludność rosyjska. Było wśród Rosjan wielu funkcjonariuszy partyjnych oraz wojskowych. Zadaniem podstawowym nowych władz była sowietyzacja i rusyfikacja. Program ten objął również miejscowych Polaków, którzy też mieli się wtopić w jeden wielki naród sowiecki. Realizowana kolektywizacja rolnictwa przy ogólnej pauperyzacji miała doprowadzić do uniformizacji wszystkich grup społecznych oderwanych od swych tradycji, religii, języka i obyczajów narodowych.

Bezpośrednio po wojnie (1947-1949) zlikwidowano definitywnie całe szkolnictwo polskie oraz organizacje promujące polskość. Powodem tej dyskryminacyjnej akcji była wrogość do tradycji polskich, kojarzonych z katolicyzmem i nastawieniem antysowieckim. Równocześnie rozpoczęło się prześladowanie Kościoła katolickiego i promowanie światopoglądu laickiego. Pomimo że nie było to skierowane bezpośrednio przeciwko ludności

11 Na temat liczebności, rozmieszczenia i sytuacji społecznej ludności polskiej na Łotwie ukazało się w okresie międzywojennym wiele interesujących publikacji. Na uwage zasługują opracowania: K. Keller (1920), E. Maliszewski (1922), J. Cynarski (1925), J. Różycki (1930), W. Sworakowski (1934). We wszystkich z nich skupiono uwagę na dziejach i losie Polaków w Łatgalii. 

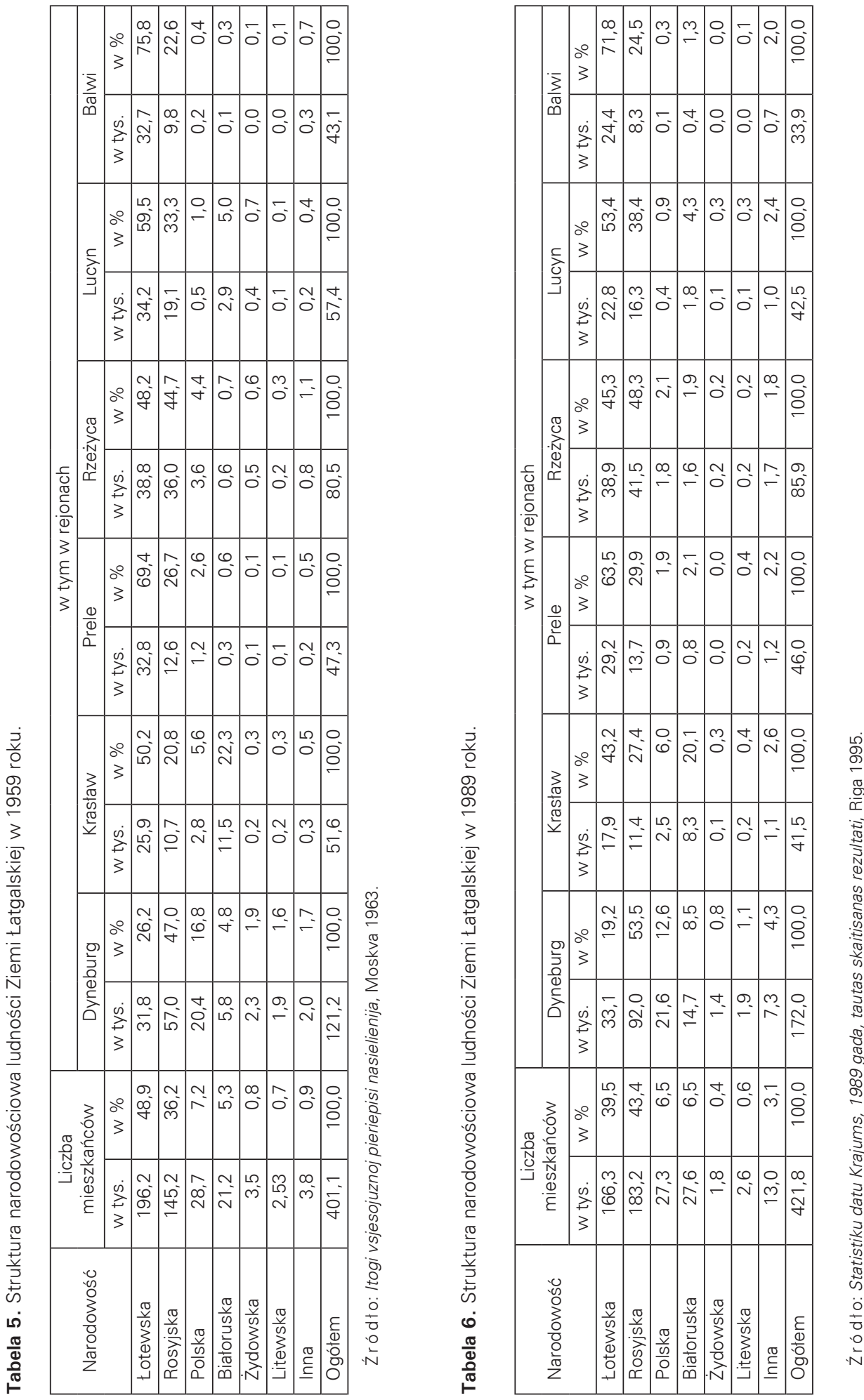
polskiej, jednak konsekwencje polityki antykatolickiej ugodziły głównie w ludność polską, gdyż jej świadomość narodowa była ściśle związana z polskojęzycznym Kościołem.

Pierwsze wiarygodne informacje o składzie narodowościowym powojennej Łatgalii uzyskano dopiero z opublikowanych wyników spisu sowieckiego zrealizowanego w 1959 roku. Uwzględniono w nim dwa kryteria etniczności: narodowość i język ojczysty. Pewnym mankamentem utrudniającym porównywanie do poprzednich spisów były zmiany administracyjne na interesującym nas obszarze. Nie przywiązywano już wagi do starych historycznych podziałów nawiązujących jeszcze do granic Inflant Polskich. Do powiatu dyneburskiego włączono dużą część powiatu Iłtukszta leżącego po południowej stronie Dźwiny. Na miejscu trzech, a w okresie międzywojennym czterech, powiatów pojawiły się trzy nowe jednostki powiatowe: Prele, Krasław i na peryferiach północnych: Balwi. Obszar Łatgalii został nieznacznie powiększony na południu i zachodzie, a pomniejszony na wschodzie po weryfikacji w rejonie Putyłowa, granicy totewsko-sowieckiej. Rezultaty spisu ujawniły na uaktualnionym terytorium Łatgalii 401,1 tys. mieszkańców. Było ich o 141 tys. mniej, niż odnotował to spis przedwojenny (1930) (tab. 5).

Ubytek demograficzny między spisami 1930 a 1959 roku wynikał z wielu przyczyn i dotyczył dekady 1940-1950. Na skutek Holocaustu uległa zagładzie większość ludności żydowskiej. Straty wojenne, bezpowrotne wyjazdy do pracy w III Rzeszy, deportacje na Syberię, likwidacja tzw. warstw posiadających, walka z antykomunistycznym podziemiem przyczyniły się do zmniejszenia ogólnego zaludnienia. Wielu młodych mieszkańców Łatgalii zostało zmobilizowanych do armii sowieckiej lub formacji wspomagających hitlerowskie Niemcy i nie wróciło już do swoich stron ojczystych.

Ludność polska Łatgalii pomimo ubytku wojennego i wyjątkowo niesprzyjających warunków przetrwała; spis wykazał w pięciu rejonach łatgalskich - 28,7 tys. osób narodowości polskiej, w tym w rejonie dyneburskim - 20,4 tys. Zmieniły się w porównaniu do okresu międzywojennego relacje między ludnością łotewską i rosyjską. Udział Łotyszy obniżył się z 56,9 do 48,9\%, zaś Rosjan wzrósł z 19,0 do 36,2\%. Pojawiły się symptomy procesu, który w następnych latach uległ przyspieszeniu. Zaprogramowana industrializacja i urbanizacja stymulowała procesy migracyjne. Do Łatgalii napływali Rosjanie, Białorusini, Ukraińcy oraz obywatele z innych republik sowieckich. Nie ulegali oni asymilacji w otoczeniu łotewskim, ale wprost przeciwnie - rozpowszechniali język rosyjski, który stawał się podstawowym językiem kontaktów międzyludzkich. Ubytek naturalny ludności łotewskiej oraz jej ujemne saldo migracyjne było przyczyną zmniejszenia na Ziemi Łatgalskiej z roku na rok liczby Łotyszy. W tym samym czasie następował demograficzny wzrost ludności rosyjskiej. Ostatni spis ludności w ZSRR odbył się w 1989 roku i ujawnił sytuację demograficzno-narodowościową w przeddzień rozpadu imperium sowieckiego (tab. 6).

W ciągu analizowanych 30 lat (1959-1989) uległy zmianie proporcje między ludnością totewską a rosyjską. Na rozpatrywanym obszarze zaczęła przeważać ludność rosyjska. Udział ludności narodowości łotewskiej obniżył się do 36,2\%. Natomiast odsetek Rosjan na Ziemi Łatgalskiej wzrósł do 43,4\%. Stali się więc Łotysze mniejszością we własnym kraju. Wynikało to gtównie ze wzrostu liczby Rosjan w samym mieście Dyneburgu i Rzeżycy, gdyż na terenach wiejskich i w małych miastach nadal zazwyczaj dominowali Łotysze. Niemniej, ewolucja przemian była wyraźnie określona i zmierzała do zredukowania i zdeprecjonowania rodzimej ludności łotewskiej. Przy zachowaniu ukształtowanych tendencji przeobrażeń zaistniała realna możliwość uzyskania przez Rosjan znacznej przewagi liczebnej i doprowadzenia do sytuacji, że Łotysze staliby się mniejszością na własnej ziemi ojczystej. Oceniając zaistniałe warunki, trzeba stwierdzić, że oderwanie się od wspól- 
noty politycznej z ZSRR oraz odzyskanie suwerenności przyszło w ostatnim momencie i uratowało naród totewski i jego język przed groźbą unicestwienia.

Liczba ludności polskiej zmniejszyła się tylko nieznacznie między 1959 a 1989 rokiem. Był to fakt dość zaskakujący przy występowaniu tak niekorzystnych uwarunkowań społecznych i ekonomicznych. Pewnym wsparciem był napływ polskich katolików z pobliskiej Białorusi. Nie stanowiło to jednak najważniejszej przyczyny zachowania polskości w Łatgalii. Można przyjąć, że tradycje katolickie były na tyle silne, że utrudniały rusyfikację, zaś różnice lingwistyczne między językiem łotewskim a polskim też stwarzały wyraźną barierę dla lettonizacji. Wieloletnia ewolucja przeobrażeń narodowościowych doprowadziła jednak do tego, że wieś łatgalska zwłaszcza położona w pobliżu Dyneburga, nabrała charakteru polietnicznego i żadna grupa narodowościowa nie była w stanie uzyskać zdecydowanej dominacji. Można to wykazać na podstawie danych odniesionych do terenów wiejskich usytuowanych w rejonie dyneburskim (tab. 7).

Tabela 7. Struktura narodowościowa ludności obszarów wiejskich rejonu Dyneburga w 1989 roku.

\begin{tabular}{|c|c|c|c|c|c|c|c|c|c|}
\hline \multirow{2}{*}{ Lp. } & \multicolumn{2}{|c|}{ Nazwa gminy } & \multirow{2}{*}{$\begin{array}{c}\text { Liczba } \\
\text { ludności }\end{array}$} & \multicolumn{6}{|c|}{ Odsetek procentowy ludności } \\
\hline & totewska & polska & & Łotysze & Rosjanie & Białorusini & Polacy & Litwini & inni \\
\hline 1. & Ambelu & Ambelujża & 974 & 56,5 & 37,9 & 1,8 & 1,5 & 0,1 & 2,2 \\
\hline 2. & Bebrenes & Bebra & 1669 & 80,3 & 12,3 & 2,1 & 2,0 & 1,4 & 1,9 \\
\hline 3. & Bikernieku & Bikierniki & 1067 & 7,2 & 81,5 & 4,8 & 2,7 & 0,3 & 3,5 \\
\hline 4. & Demenes & Demmen & 1471 & 12,9 & 39,3 & 14,5 & 29,4 & 0,8 & 3,1 \\
\hline 5. & Dubnas & Dubno & 1106 & 48,6 & 38,5 & 4,0 & 4,0 & 0,4 & 4,5 \\
\hline 6. & Dvietes & Dweta & 816 & 86,5 & 6,5 & 0,9 & 2,3 & 1,3 & 2,5 \\
\hline 7. & Eglaines & Jelówka & 1349 & 43,8 & 40,9 & 3,6 & 3,5 & 5,3 & 3,3 \\
\hline 8. & Kalkunes & Kałkuny & 2669 & 16,7 & 51,2 & 9,4 & 17,6 & 2,9 & 2,2 \\
\hline 9. & Kalupes & Kałup & 2091 & 51,1 & 37,5 & 1,9 & 2,9 & 0,3 & 6,3 \\
\hline 10. & Laukezes & Łankiesy & 1640 & 8,2 & 52,8 & 10,1 & 24,2 & 3,0 & 1,7 \\
\hline 11. & Lidumnieku & Lidumniek & 808 & 7,8 & 56,3 & 14,9 & 18,2 & 0,1 & 2,9 \\
\hline 12. & Liksnas & Liksna & 1410 & 80,5 & 10,7 & 4,7 & 2,8 & 0,1 & 1,2 \\
\hline 13. & Malinovas & Malinówka & 1197 & 17,3 & 65,8 & 6,7 & 3,7 & 0,8 & 5,7 \\
\hline 14. & Medumu & Medum & 1523 & 10,9 & 46,3 & 6,7 & 24,6 & 7,4 & 4,1 \\
\hline 15. & Naujenes & Józefowo & 7077 & 22,8 & 54,2 & 7,9 & 8,2 & 0,7 & 6,2 \\
\hline 16. & Nicgales & Nicgal & 1284 & 54,5 & 29,5 & 5,3 & 3,2 & 0,8 & 6,7 \\
\hline 17. & Piliskaines & Szlosberg & 1311 & 68,3 & 11,5 & 5,1 & 11,1 & 3,1 & 0,9 \\
\hline 18. & Salienas & Sałonaje & 1011 & 13,8 & 49,6 & 10,9 & 22,0 & 0,6 & 3,1 \\
\hline 19. & Skrudalienas & Skrudelino & 1881 & 7,0 & 58,1 & 14,8 & 17,2 & 0,8 & 2,1 \\
\hline 20. & Sventes & Swentet & 1511 & 19,9 & 35,2 & 9,1 & 32,2 & 1,7 & 1,9 \\
\hline 21. & Sederes & Schodem & 1696 & 47,0 & 33,9 & 4,4 & 9,3 & 3,7 & 1,7 \\
\hline 22. & Taboras & Tabor & 1215 & 11,7 & 49,2 & 16,5 & 19,8 & 0,4 & 2,4 \\
\hline 23. & Vaboles & Wabol & 1101 & 86,8 & 7,7 & 1,5 & 1,3 & 0,3 & 2,4 \\
\hline 24. & Vecsalienas & \begin{tabular}{|l} 
Stare \\
Sołonoje
\end{tabular} & 909 & 14,6 & 48,2 & 16,3 & 17,6 & 0,4 & 2,9 \\
\hline 25. & Visku & Wyszki & 3147 & 48,3 & 39,7 & 5,2 & 4,2 & 0,4 & 2,2 \\
\hline 26. & Subates & Subocz & 401 & 87,9 & 11,2 & 2,9 & - & 6,4 & 1,6 \\
\hline \multicolumn{3}{|c|}{ Ogółem } & 42334 & 35,2 & 41,5 & 7,3 & 11,1 & 1,5 & 3,4 \\
\hline
\end{tabular}

Źr ó d ło: Statistiku datu Krajums, 1989 gada tautas skaitisanas rezulteti Latcija, Riga 1992. 
Rozmieszczenie ludności poszczególnych narodowości było zróżnicowane w układzie terytorialnym. Świadczy o tym skład narodowościowy określony dla każdej pojedynczej gminy. Stopień dyspersji wyrażony udziałem procentowym każdej z narodowości w ujęciu gminnym jest niezmiernie wysoki. Udział procentowy Łotyszy mieści się w granicach od 7,0 do 87,9\%, Rosjan od 6,5 do 81,5\%, zaś Polaków od 1,5 do 32,2\%. Każda gmina w powiecie dyneburskim ma swoją odrębną, niepowtarzalną specyfikę narodowościową. Mieszkają więc obok siebie mieszkańcy reprezentujący różne wspólnoty narodowościowe. Z tego też powodu większość małżeństw na tym obszarze ma charakter międzyetniczny, a dzieci urodzone w rodzinach mieszanych mają w takiej sytuacji trudność z określeniem własnej narodowości. Było to między innymi przyczyną rusyfikacji, gdyż wybór języka rosyjskiego, a następnie opcji rosyjskiej, zapewniał najdogodniejszy start w dojrzałe życie zawodowe.

\section{WSPÓtCZESNA SYTUACJA NARODOWOŚCIOWA}

Restytucja niepodległego państwa łotewskiego przyniosła poważne konsekwencje demograficzno-narodowościowe. W odróżnieniu od wydarzeń politycznych przemiany w zakresie stosunków demograficznych czy etnicznych mają charakter ewolucyjny i przebiegają stopniowo. Zmiana warunków politycznych wpłynęła na pozycję poszczególnych grup narodowościowych. Łotysze stali się gospodarzami we własnym kraju. Uzyskali pozycję nie tylko równoprawną, ale nawet uprzywilejowaną. Ludność rosyjska znalazła się po odzyskaniu przez Łotwę niepodległości w bardzo trudnych warunkach socjalnych i politycznych. Straciła bezpowrotnie wpływ na kierowanie państwem. Nie znając języka łotewskiego, który uzyskał rangę jedynego języka państwowego, stała się elementem obcym i niepożądanym. Nowe warunki rosyjscy mieszkańcy Łotwy traktują jako dyskryminację i zamach na prawa obywatelskie.

Ludność rosyjska stanęła przed trudnym dylematem. Pierwsza możliwość wiązała się z podjęciem decyzji migracyjnej i wyjazdem do Rosji. Alternatywą było zostanie na miejscu i dopasowanie się do nowej roli, tzn. obywatela należącego do mniejszości narodowej. Ze względu na różnice kulturowe i językowe wtopienie się w społeczeństwo łotewskie nie jest łatwe. Nałożyły się na to obiektywne przesłanki ekonomiczne. Rosyjska kadra urzędnicza utraciła pracę. Upadek zakładów przemysłowych wywołał bezrobocie. Wycofanie armii rosyjskiej spowodowało exodus rosyjskojęzycznej kadry oficerskiej. Zmieniły się kierunki migracyjne. Napływ ludności rosyjskojęzycznej ustał. Z kolei wielu Rosjan, Białorusinów i Ukraińców postanowiło opuścić Łotwę. W pierwszym okresie po zmianach politycznych odpływ migracyjny z Łotwy miał charakter spontaniczny. W ciągu pierwszych kilku lat niepodległości ujemne saldo migracyjne wyniosło blisko 100 tys. osób. W przybliżeniu tylu Rosjan opuściło bezpowrotnie Łotwę. W następnym okresie wyjazdy uległy zahamowaniu. Przy tak licznej diasporze rosyjskiej nie mogło to wpłynąć w sposób bardziej zasadniczy na relacje narodowościowe. Nadal bowiem mniejszość rosyjska jest liczna, a mając wsparcie w Moskwie, może działać dezintegrująco na życie kraju. Odpływ migracyjny z Łatgalii był mniejszy niż z zachodniej Łotwy. Ludność rosyjska na wielu obszarach należących do tej części kraju dominowała i odczuwała mniejsze zagrożenie i bardziej skutecznie mogła się przeciwstawić presji łotewskiej.

Wyjazdy migrantów rosyjskich z Łatgalii miały podobny przebieg i charakter jak z innych rejonów Łotwy. W pierwszym rzędzie wyjeżdżali funkcjonariusze zatrudnieni w apa- 
racie partyjnym i administracyjnym, kadra techniczna z likwidowanych zakładów przemysłowych, korpus oficerski oraz pracownicy służby bezpieczeństwa. W mniejszym stopniu wyjazdy objęły rosyjskich robotników. Brak znajomości języka łotewskiego nie stanowił dla nich zasadniczej bariery przy poszukiwaniu zatrudnienia.

Podobnie jak na całym obszarze postsowieckim wystąpiły w Łatgalii negatywne zjawiska w ruchu naturalnym ludności. Obniżyła się skala urodzeń oraz nastąpił skokowy wzrost umieralności. Było to spowodowane trudnymi warunkami bytowania, kryzysem ekonomicznym i załamaniem dotychczasowego systemu opieki społecznej, który, pomimo niewysokiego standardu, gwarantował jednak minimum socjalne. Dotychczasowy system ustrojowy uległ likwidacji, a nowy nie był w stanie się uformować. Wpłynęło to w sposób nieunikniony na warunki życia oraz na sytuację demograficzną. Niewielki przyrost naturalny istniejący do końca lat 80 . zmienił się w ubytek naturalny. Liczba zgonów wzrosła, zaś liczba urodzonych dzieci z roku na rok malała. Zaludnienie Łatgalii analogicznie jak całej Łotwy zaczęło się stopniowo zmniejszać. Według spisu powszechnego z 1989 roku liczba ludności Łatgalii wynosiła 421,8 tys. Przeprowadzony spis w 2000 roku na tym samym obszarze wykazał jedynie 381,9 tys., czyli w ciągu 11 lat zaludnienie obniżyło się o ok. 40 tys. osób (tab. 8).

W ciągu całego długiego okresu sowieckiego mieliśmy do czynienia ze stałym zwiększaniem się zaludnienia ludności narodowości rosyjskiej. Po odzyskaniu niepodległości tendencje demograficzne uległy odwróceniu. Liczebność Rosjan obniżyła się między 1989 a 2000 rokiem w Łatgalii o 29,2 tys., w tym samym czasie liczba Łotyszy utrzymywała się w zasadzie na tej samej wysokości (1989 r. - 166,3 tys., 2000 r. - 165,1 tys.). Po raz pierwszy od kilku dziesięcioleci wzrósł udział procentowy ludności łotewskiej w zaludnieniu w Łatgalii, a mianowicie z 39,5 do 43,2\%, zaś odsetek Rosjan zmniejszył się z 43,4 do $40,3 \%$. Nadal jednak Rosjanie przeważają w Dyneburgu. W mieście tym relacje między poszczególnymi grupami narodowościowymi są w miarę stałe, przy utrzymującej się znacznej dominacji Rosjan. Według danych spisu sowieckiego z 1989 roku w Dyneburgu Rosjanie stanowili 58,3\%, zaś w 2000 roku - 55,1\% zaludnienia. Udział Łotyszy wzrósł między tymi dwoma przekrojami czasowymi z 13,0 do 16,1\%.

Najbardziej aktualne dane odnoszące się do składu narodowościowego Łatgalii dotyczą roku 2009 i są zestawione według pięciu rejonów, na które podzielona jest Łatgalia (ryc. 4). Według tych szacunkowych, lecz wiarygodnych informacji statystycznych, liczba ludności rozpatrywanej prowincji nadal się obniża i wynosiła w końcu tego roku 343,6 tys., czyli w stosunku do 2000 roku zmniejszyła się o 38,0 tys. Doliczając regres z lat 19892000, ubytek w ciągu analizowanych dwóch dekad doszedł do blisko 80 tys. osób i objął wszystkie pięć rejonów Łatgalii (tab. 9).

W miare upływu lat zwiększa się udział ludności totewskiej (1989 r. - 39,5\%, 2000 r. - 43,2\%, 2009 r. - 44,0\%), a maleje odsetek Rosjan (1989 r. - 43,4\%, 2000 r. - 40,3\%, 2009 r. $-39,2 \%$ ). Proces ten jest powolny, ale tendencje z okresu sowieckiego zostały odwrócone. We wszystkich rejonach pozycja Łotyszy znacznie się umocniła. W samym Dyneburgu Rosjanie nadal dominują (2000 r. - 55,1\%, 2009 r. - 52,8\%). Udział Łotyszy w stolicy prowincji jest niski, ale po 2000 roku sukcesywnie wzrasta (2000 r. - 16,1\%, 2009 r. - 17,6\%). W coraz większym stopniu administracja jest w rękach Łotyszy, lecz językiem używanym powszechnie przez ludność jest nadal język rosyjski, którym posługują się obok Rosjan również Białorusini i Polacy. Władze łotewskie, zdając sobie sprawę z utrwalonej przez dziesięciolecia sytuacji, nie próbują tego w sposób radykalny zmienić. Każde tego typu posunięcie dyskryminujące język rosyjski zakończyłoby się niepowodze- 

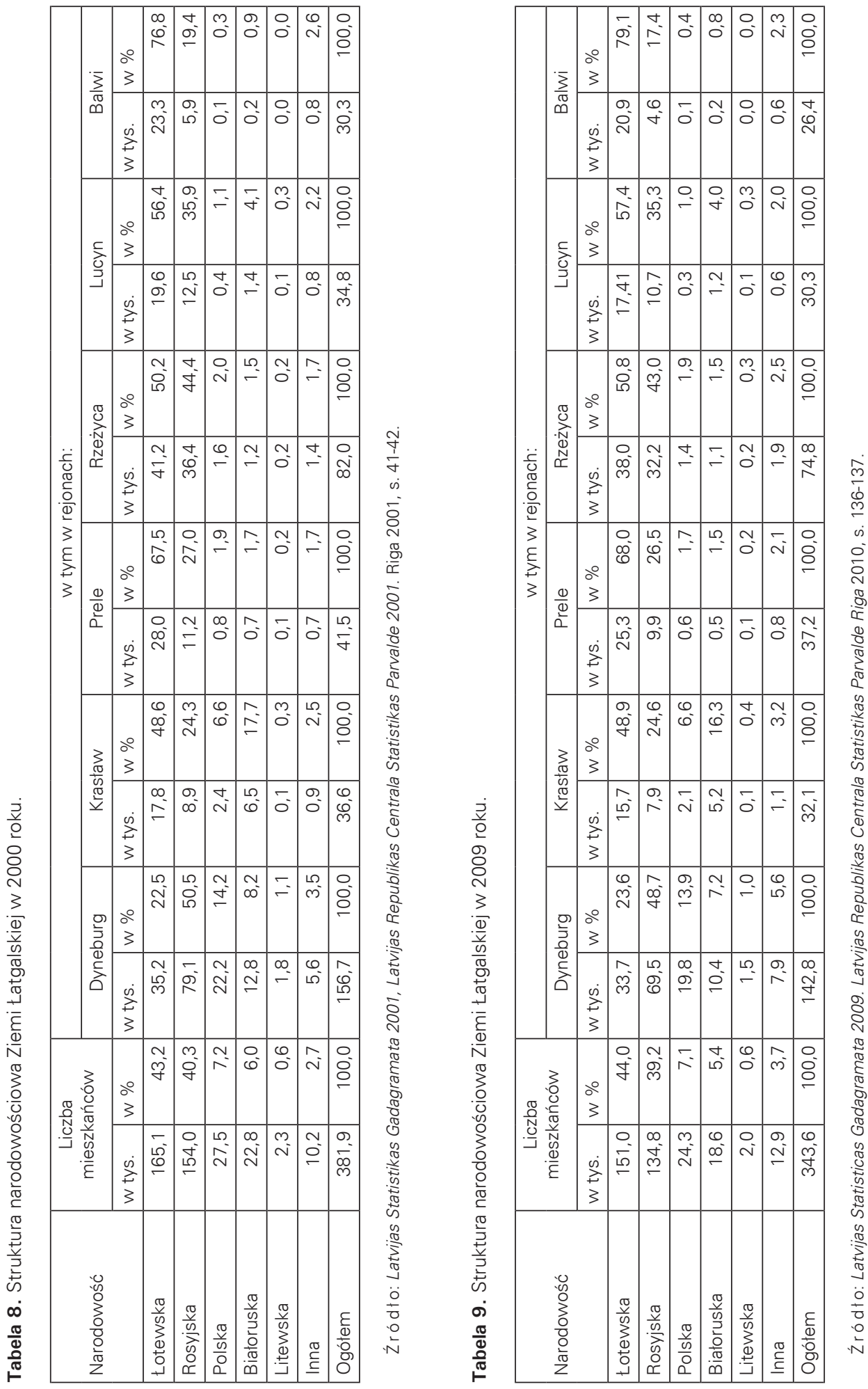


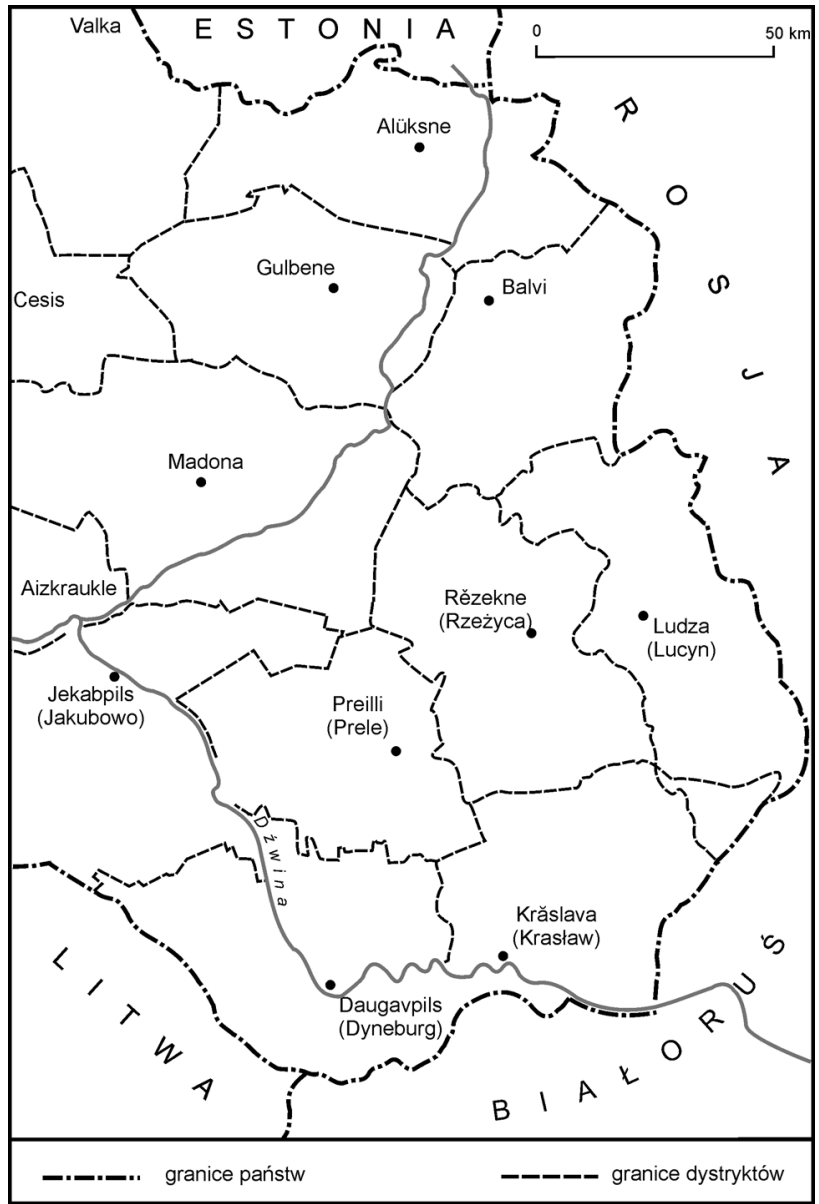

Ryc. 4. Łatgalia w granicach współczesnej Łotwy.

Żródło: Latvija. Nacionălais sastăvs. National structure, Apgăds "Jana Sěta", Riga; Baltische Lande, Die „Deutschen Ostseeprovinzen" Russlands 1888, [w:] Staats- und Verwaltungs-Grenzen in Ostmitteleuropa, Verlag von r. Oldenbourg, 1954, München.

niem. Dlatego też podejmują działania o charakterze długofalowym. Głównie polega to na wprowadzeniu do szkolnictwa rosyjskiego, jako dodatkowego, języka łotewskiego. Ma to na celu doprowadzenie wśród młodszej generacji do dwujęzyczności. Procesy te będą zachodziły szybciej w północnej i zachodniej Łatgalii. W części południowo-wschodniej przylegającej do Dźwiny, w których zdecydowanie dominuje ludność słowiańska (Rosjanie, Białorusini, Polacy), nie należy oczekiwać zmian językowych, a tym bardziej świadomościowych. Proces oficjalnej lettonizacji językowej jest utrudniony, gdyż nawet miejscowi Łotysze posługują się w życiu codziennym dialektem łatgalskim i słaba jest wśród nich znajomość literackiego języka łotewskiego. Z tego też powodu nie należy oczekiwać radykalnych zmian w przyszłości. W ciągu wieków Łatgalia miała zawsze swoją odrębną specyfikę demograficzno-etniczną i tę odmienność w przyszłości również zachowa. W dodatku Łatgalia jest najbiedniejszą prowincją łotewską, co też utrudnia rozwój i modernizację i jest przyczyną permanentnej stagnacji i marazmu. 
Długi okres sowiecki wpłynął w sposób istotny na kondycję narodową miejscowych Polaków. Zatracili oni w dużym stopniu język ojczysty. Był on jeszcze powszechnie używany w latach bezpośrednio powojennych. Następnie postępowała stopniowa językowa rusyfikacja. Znajomość języka łotewskiego nie była zbyt potrzebna, gdyż w Dyneburgu jak i w jego okolicach językiem porozumiewania i kontaktów w życiu publicznym był język rosyjski. Dyskryminacja Kościoła rzymskokatolickiego oraz bezwzględna ateizacja zwłaszcza dzieci i młodzieży sprzyjała depolonizacji. Przetrwanie więc polskości w Łatgalii było zjawiskiem raczej nieoczekiwanym. Na pobliskiej Litwie w pobliżu Kowna czy Poniewieża, podobnie liczna mniejszość polska poddana lituanizacji trwającej siedemdziesiąt lat (19201990) uległa zanikowi. Tymczasem w łotewskiej Łatgalii w kolejnych spisach łotewskich, następnie sowieckich i znowu łotewskich, kilkadziesiąt tysięcy tutejszych mieszkańców konsekwentnie deklarowało narodowość polską. Przypuszczalnie wynikało to z innego stosunku Łotyszy czy Rosjan do Polaków mieszkających nad Dźwiną niż Litwinów do kowieńskich Polaków. Nie kwestionowano w Łatgalii ich rodowodu polskiego, co było powszechne na Litwie, i mniej wrogo odnoszono się do ich identyfikacji narodowej.

O utrzymaniu polskiej świadomości wśród licznych mieszkańców Łatgalii świadczą wydarzenia z przełomu lat 80. i 90. XX wieku. Bezpośrednio po upadku komunizmu i rozpadzie ZSRR nastąpiło spontaniczne odrodzenie organizacji polonijnych. Pierwszym zwiastunem było powstanie w sierpniu 1988 roku w Dyneburgu Ośrodka Kulturalno-Oświatowego Polaków "Promień", do którego akces złożyło ok. 1000 osób. Następnym krokiem było reaktywowanie Związku Polaków na Łotwie, który w sposób jednoznaczny nawiązał do chlubnych tradycji okresu międzywojennego. Po kilku latach dzięki mobilizacji miejscowych Polaków oraz wsparciu władz miejskich uzyskano odpowiednio dużą siedzibę w centrum Dyneburga, w której ulokowano "Dom Polski”. Znajduje się w nim od 1997 roku Centrum Kultury Polskiej, które prowadzi działalność zmierzającą do promowania języka i kultury polskiej. Ponadto w Dyneburgu powstały dwie polskie biblioteki. Nadawane są również polskojęzyczne audycje radiowe i telewizyjne. Najważniejszym zadaniem Związku Polaków na Łotwie jest rozwój polskiego szkolnictwa. Powstała polska szkoła w Dyneburgu i Krasławiu oraz w kilku innych okolicznych miejscowościach wprowadzono do nauczania język polski. Kolejnym wydarzeniem przełomowym był kres prześladowań, dyskryminacji Kościoła rzymskokatolickiego. Podobnie jak na całym obszarze postsowieckim nastąpił renesans życia religijnego. Powstały nowe lub odtworzono stare parafie. W wielu z nich odbywają się nabożeństwa w języku polskim. Wpłynęło to integrująco na społeczności lokalne, które zawsze traktowały katolicyzm jako ostoję polskości².

Należy jednak stwierdzić, że po kilkuletnim okresie entuzjazmu, który panował w latach 90., obecna polska działalność społeczna przynosi mniej spektakularne rezultaty. Wynika to ze zmian pokoleniowych. Dla najmłodszej generacji pewne fakty historyczne są już mniej ważne. Wielu młodych ludzi z rodzin polskich jest zainteresowanych bardziej emigracją lub działalnością zawodową niż pielęgnowaniem tradycyjnych wzorców nawiązujących do odległej przeszłości. Ta zmiana nastawienia do pryncypiów narodowych ma charakter bardziej uniwersalny i nie dotyczy wyłącznie mniejszości polskiej.

Należy uznać z satysfakcją, że po kilkunastu latach działalności Związek Polaków na Łotwie okrzepł organizacyjnie, utworzył filie terenowe i nadal aktywnie działa na rzecz

12 Ze względu na opublikowanie kilku opracowań poświęconych życiu współczesnej Polonii łotewskiej, a przede wszystkim łatgalskiej, nie zachodzi potrzeba wnikania w kwestie szczegółowe, które są zaprezentowane między innymi w obszernej zbiorowej książce przygotowanej przez zespół socjologów (Polacy 2009). W zamieszczonych artykułach autorskich podane są szczegółowe informacje o warunkach życia Polaków nad Dźwiną (np. A. Herman 2009, G. Makowski 2009). 
Polonii łatgalskiej. Stosunki jego z władzami łotewskimi są poprawne. Na uniwersytecie dyneburskim istnieje Zakład Polonistyki, którego absolwenci zasilają polskie szkolnictwo. Uformowała się ponadto grupa historyków łotewskich, którzy przypominają dzieje Inflant Polskich i z wielkim uznaniem oceniają historyczny dorobek polskiej kultury ${ }^{13}$. W odróżnieniu od stosunków polsko-litewskich na Wileńszczyźnie, relacje polsko-łotewskie w Łatgalii układają się bezkonfliktowo. Trudno przewidzieć, co przyniesie przyszłość. Na razie polskości nad Dźwiną nic nie zagraża. Można jedynie założyć, że stopniowe procesy asymilacyjne są nie do uniknięcia. Będą one zmierzały w dalszym horyzoncie czasu bardziej do lettonizacji niż rusyfikacji.

\section{BIBLIOGRAFIA}

Albin J., 1993, Organizacja polska na Łotwie w latach miedzywojennych, w: [Polacy na Łotwie], red. ks. E. Walewander, Katolicki Uniwersytet Lubelski, Lublin, s. 173-202

Albin J., 1993, Polski ruch narodowy na Łotwie w latach 1919-1940, Acta Universitatis Wratislaviensis, Wrocław

Buczyński M., 1993, Recepcja totewskich nazw geograficznych w jezyku polskim, w: [Polacy na Łotwie], red. ks. E. Walawander, Katolicki Uniwersytet Lubelski, Lublin, s. $103-112$

Byczkowski J., 1992, Z dziejów Polaków na Łotwie w XX wieku, w: [Mniejszości polskie i Polonia w ZSRR], red. H. Kubiak i in., Zakład Narodowy im. Ossolińskich Wrocław, Warszawa, Kraków, s. 351-362

Cynarski J. (Krzesławski), 1925, Łotwa współczesna, Biuro Społeczne Literackie, Warszawa

Durejko A., 2001, Polskie życie kulturalne i literackie na Łotwie w XX wieku, Wyd. Sudety, Wrocław

Dybciak K., 1993, Ziemie łotewskie w polskiej literaturze i historiografii XX w., w: [Polacy na Łotwie], red. ks. E. Walawander, Katolicki Uniwersytet Lubelski, Lublin, s. 73-102

Eberhardt P., 1997, Liczebność i rozmieszczenie ludności polskiej na Łotwie, "Czasopismo Geograficzne" T. LXVIII z. 3-4, Warszawa, s. 287-310

Eberhardt P., 1998, Problematyka narodowościowa Łotwy, "Zeszyty IGiPZ PAN" nr 54, Instytut Geografii i P.Z. PAN, Warszawa

Herman A., 2009, Polsko-łatgalska kultura w Dyneburgu, w: [Polacy nad Dźwiną, red. J. Kurczewski, M. Fuszara, wyd. Uniwersytetu Warszawskiego, Warszawa, s. 133-176

Hlebowicz S., 1992, Kościół Katolicki na Łotwie (1944-1991), "Więź” nr 6 (404), Warszawa, s. 120-130

Jēkabsons E., 1993, Stosunki polsko-litewskie na przestrzeni dziejów, w: [Polacy na Łotwie], red. ks. E. Walawander, Katolicki Uniwersytet Lubelski, Lublin, s. 23-72

Keller K., 1920, Stosunki narodowościowe, społeczne, ekonomiczne na Inflantach Polskich i polityczne w Łatgalii, Wyd. Ksieggarsko-Drukarska S-ka, Rypin

Kolbuszewski J., 1992, Polacy na Łotwie. Historia i współczesność. Zarys problematyki, w: [Mniejszości polskie i Polonia w ZSRR], red. E. Kubiak i in., Zakład Narodowy im. Ossolińskich, Wrocław, Warszawa, Kraków, s. 331-350

13 Dużą rolę odgrywa działalność twórcza i popularyzatorska historyka łotewskiego E. Jēkabsonsa, który stał się autorytetem w zakresie badań nad stosunkami polsko-łotewskimi. 
Korzeń J. (Roszkowski W.), 1987, Dramat narodów bałtyckich Pokolenie, Warszawa

Kultura polska na Łotwie, 1994, red. J. Sozański, R. Szklennik, Wyd. Ambasada Rzeczypospolitej Polskiej, Ryga

Łossowski P., 1990, Łotwa nasz sąsiad. Stosunki polsko-łotewskie, Wyd. Mozarka, Warszawa

Makowski G., 2009, Polskie organizacje w Daugavpils, w: [Polacy nad Dźwiną], red. J. Kurczewski, M. Fuszara, wyd. Uniwersytetu Warszawskiego, Warszawa, s. 123-152

Maliszewski E., 1992, Polacy na Łotwie, Wyd. Towarzystwa Straży Kresowej, Warszawa

Manteuffel-Szoege R., 1991, Inflanty, Inflanty... wspomnienia rodzinne, Ludowa Spółdzielnia Wydawnicza, Warszawa

Manteuffel G., 1879, Inflanty Polskie poprzedzone ogólnym rzutem oka na siedmiowiekową przeszłość całych Inflant, Księgarnia J.K. Żupańskiego, Poznań

Manteuffel G., 2007, Zarysy z dziejów krain dawnych inflanckich: czyli Inflant właściwych (tak szwedzkich jako i polskich), Estonii z Ozylią, Kurlandii i Ziemi Pilityńskiej, Wyd. Universitas, Kraków

Paluszyński T., 2003, Kurlandia, Inflanty i Estonia pod obcą władzą (Panowanie niemieckie, polskie i szwedzkie). Zarys historii politycznej regionu od początku XII wieku do roku 1721/1795, w: [Łotwa. Wczoraj - dziś - jutro], red. T. Paluszyński i in., Wyd. Studio, Poznań, s. 11-31

Polacy nad Dźwiną, 2009, red. J. Kurczewski, M. Fuszara, Wyd. Uniwersytetu Warszawskiego, Warszawa

Polska a Inflanty, 1939, red. J. Borowik, Wyd. Instytut Battycki, Gdynia

Romanowski A., 1996, Inflanty i polski raj, w: [„Tygodnik Powszechny” nr 28 (2453)], Kraków, s. 5-6

Różycki J., 1930, Polacy na Łotwie, Wyd. im. A. Mickiewicza, Warszawa

Sworakowski W., 1934, Polacy na Łotwie, Instytut Badań Spraw Narodowościowych, Warszawa

Zajas K., 2008, Nieobecna Kultura. Przypadek Inflant Polskich, Wyd. Universitas, Kraków

POPULATION CHANGES IN LATGALE

\section{Summary}

Latgale is one of the four provinces of Latvian State. It is located in the east part of the Latvia that borders with Byelorussia and Russia. The first part of this article presents Latgale's history since the $13^{\text {th }}$ century. Latgale was part of Poland (Polish Inflants, 1561-1772), and later of Russian Empire (1772-1916). The Russian census of 1897 shows that it was inhabited by various nations: Latvians, Russians, Jews, Poles, Belarusians and Latvians.

The next part of the article deals with the demographic situation in the interwar period when Latgale was an integral part of the sovereign Latvian state. Later, together with whole Latvia, it was incorporated into the Soviet Union in 1940; next it was occupied by Nazi Germany, and again incorporated to the Stalin's Soviet Union. As it became part of Latvian Soviet Republic, it was subjected to planned russification and sovietization policies to eliminate its national and confessional diversity. There was then a mass influx of the Russian people, while the local Latvian population was marginalized. These changes are presented in the text on the basis of the Soviet censuses of 1959 and 1989. The author 
- PIOTR EBERHARDT

also discusses relations between Russian and Latvian populations, as well as the number and distribution of population of the Polish origin, who traditionally concentrated in Daugavpils and its vicinity.

The last part of the article deals with the period after the collapse of the Soviet Union and the regaining of independence by Latvia. The nationality evolution is presented on the basis of statistical data from 2000 and 2009. The present Latvian authorities aim at strengthening the national character of the state and limiting the significance of its numerous Russian minority. The information on the current condition of the local Polish population closes the text.

Keywords: Latgale, Polish Inflants, nationality structure, population changes 